\title{
Comprehensive Utilization of Thinned Unripe Fruits from Horticultural Crops
}

\author{
Mengyuan Wei ${ }^{1}$, Haoli Wang ${ }^{1}$, Tingting Ma ${ }^{1}\left(\mathbb{D}\right.$, Qian Ge ${ }^{1,2}$, Yulin Fang ${ }^{1}$ and Xiangyu Sun ${ }^{1, *(D)}$ \\ 1 College of Enology, College of Food Science and Engineering, Viti-Viniculture Engineering Technology Center \\ of State Forestry and Grassland Administration, Shaanxi Engineering Research Center for Viti-Viniculture, \\ Heyang Viti-viniculture Station, Northwest A\&F University, Yangling 712100, China; \\ weimengyuan@nwafu.edu.cn (M.W.); Wangholy@nwafu.edu.cn (H.W.); matingting@nwafu.edu.cn (T.M.); \\ geqian1116@shou.com (Q.G.); fangyulin@nwsuaf.edu.cn (Y.F.) \\ 2 Quality Standards and Testing Institute of Agricultural Technology, Yinchuan 750002, China \\ * Correspondence: sunxiangyu@nwafu.edu.cn; Tel./Fax: +86-29-8709-2486
}

Citation: Wei, M.; Wang, H.; Ma, T.; Ge, Q.; Fang, Y.; Sun, X.

Comprehensive Utilization of

Thinned Unripe Fruits from Horticultural Crops. Foods 2021, 10, 2043. https://doi.org/10.3390/ foods10092043

Academic Editors: Débora Campos and Ana Raquel Madureira

Received: 15 July 2021

Accepted: 24 August 2021

Published: 30 August 2021

Publisher's Note: MDPI stays neutral with regard to jurisdictional claims in published maps and institutional affiliations.

Copyright: (c) 2021 by the authors. Licensee MDPI, Basel, Switzerland. This article is an open access article distributed under the terms and conditions of the Creative Commons Attribution (CC BY) license (https:/ / creativecommons.org/licenses/by/ $4.0 /)$.

\begin{abstract}
Fruit thinning is a cultivation technique that is widely applied in horticulture in order to obtain high-quality horticultural crops. This practice results in the discarding of a large number of thinned unripe fruits in orchards each year, which produces a great waste of agricultural resources and causes soil pollution that may be an important reservoir for pest and plant diseases. Current studies showed that bioactive compounds such as polyphenols, organic acids, monosaccharides and starches are present in unripe fruits. Therefore, we reviewed the bioactive components obtained from thinned unripe fruits, their revalorization for the food industry, their beneficial effects for human health and the methods for obtaining these components. We also performed a calculation of the costs and benefits of obtaining these bioactive compounds, and we proposed future research directions. This review provides a reference for the effective utilization and industrial development of thinned unripe fruits obtained from horticultural crops. Furthermore, revalorizing the waste from this cultural practice may increase the economic benefits and relieve the environmental stress.
\end{abstract}

Keywords: horticultural crops; thinned unripe fruits; phenolic bioactive compounds; non-phenolic bioactive compounds; comprehensive utilization

\section{Introduction}

Thinning is the removal of individual fruits after fruit set [1,2]. Many fruit species support a variable amount of fruit and have self-regulatory mechanisms for natural fruit dropping. However, trees are frequently unable to support fruit productivity using only self-regulating mechanisms [3-8]. For most horticultural crops, relying on falling off by themselves prevents an optimal crop load for the production of ripe fruits, with a balance of quality and quantity, and exogenous intervention is needed to achieve these goals. Seehuber et al. [9] reported that the nutritional composition of fruits, fruit size, yield, fruit shape and number of seeds were affected by fruit thinning. The sugar content, $\mathrm{pH}$ and mineral composition of fruits were also affected. To perform fruit thinning, some of the developing unripe fruits are removed to allow the remaining unripe fruits to have more photosynthetic products available to increase fruit size and improve quality [10-12]. Fruit thinning is also one of the best cultivation practices that may increase flower return the following season [13]. Fruit thinning balances the fruit-to-shoot ratio and increases the availability of nutrients for fruits, shoots and reserve organs [14].

Therefore, many horticultural crops, such as grapes, apples, peaches, pears, pomegranates, citruses, and cherries, need fruit thinning in their crop management strategies (Figure 1). Due to the need to improve fruit quality in crop management by physiological drop or fruit thinning, a large number of unripe fruits are discarded every year. For example, the production of grapes and apples in China generates relatively few thinned fruits. The 
amount of thinned fruits per acre is 30-60 kg for grapes [15], 30-50 kg for apples [16,17], nearly $100 \mathrm{~kg}$ for peaches and pears [15,18], and 280-400 kg for pomegranates [19].

A

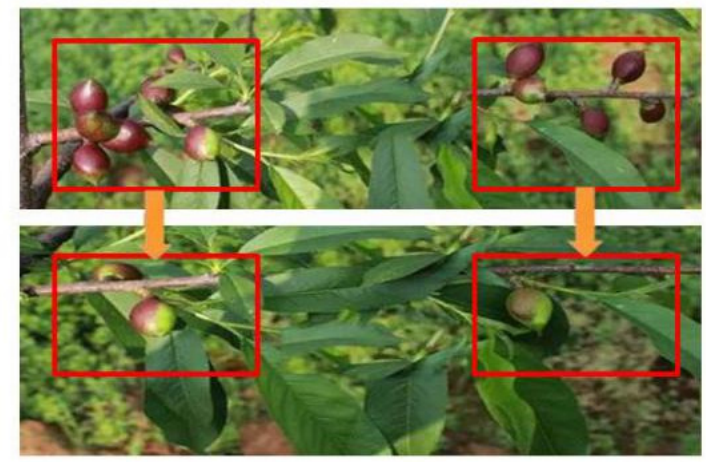

C
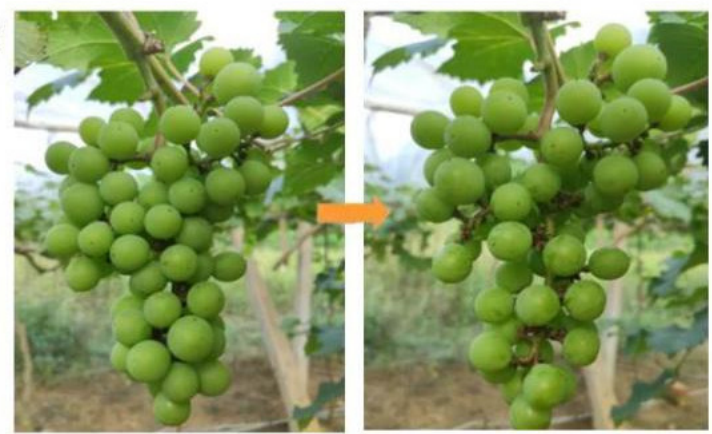

B

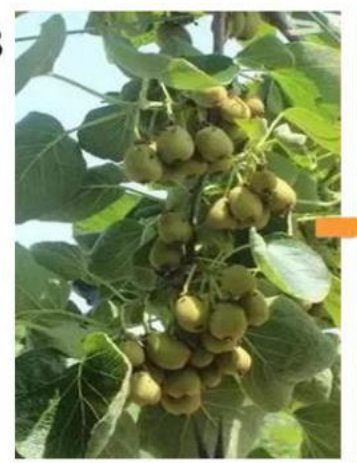

D

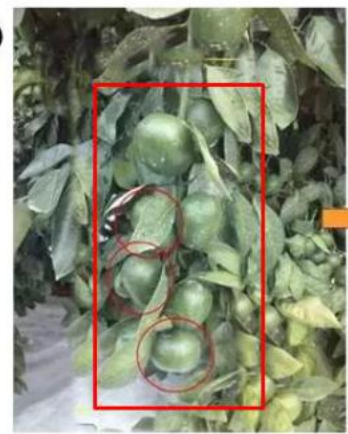

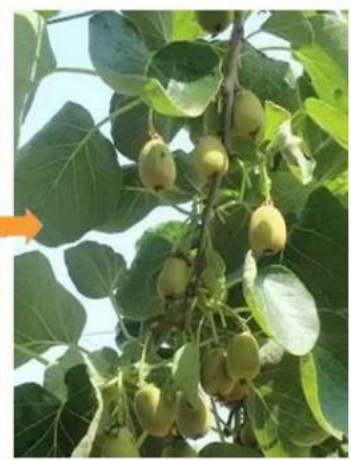

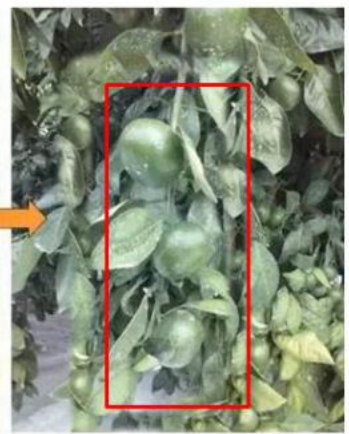

Figure 1. Thinning fruit: (A) peach, (B) kiwifruit, (C) grape, (D) and citrus.

Thinning fruit improves the economic value of horticultural crops. However, the careless handling of thinned unripe fruits will cause variable harm to the soil, plants and environment. The traditional utilization of some discarded unripe fruits could reduce the toxicity of the soil environment. Some farmers use unripe thinned fruits as poultry feed [20]. In the tropics, sheep feed is generally based on corn and soybean which must be imported from abroad. Archimède de et al. [21] substituted the imported feed with local food resources and reported that unripe discarded bananas together with local forages replaced the conventional protein supplements of corn and soybean in sheep feed. Orange waste is also effective in reducing the fat content of poultry and increasing meat content $[22,23]$. Additionally, discarded unripe fruits may also be used together with other agricultural wastes for composting, power generation, and fuel extraction [15,24].

In recent years, many researchers have found bioactive compounds, such as polyphenols, organic acids, monosaccharides and starches. These are important parts of unripe fruits, and are potential beneficial resources in many industries such as human health, food preservation, functional foods, and industrial materials (Figure 2) [25-31]. Thinned unripe fruit utilization opens new paths for orchard management and would increase the economic benefits for agricultural workers [32]. Although the usefulness of these bioactive compounds in unripe fruit was verified in many experiments, applications with high added value are still in the laboratory rather than in the factory. Most extraction methods and other applications of these high-added-value components have many disadvantages. For example, some bioactive components are susceptible to inactivation. On the other hand, the high cost of the extracting bioactive compounds from unripe fruit is an outstanding issue [33]. Therefore, the utilization and development of extraction methodologies for bioactive compounds and other applications of discarded unripe fruit require further study. 


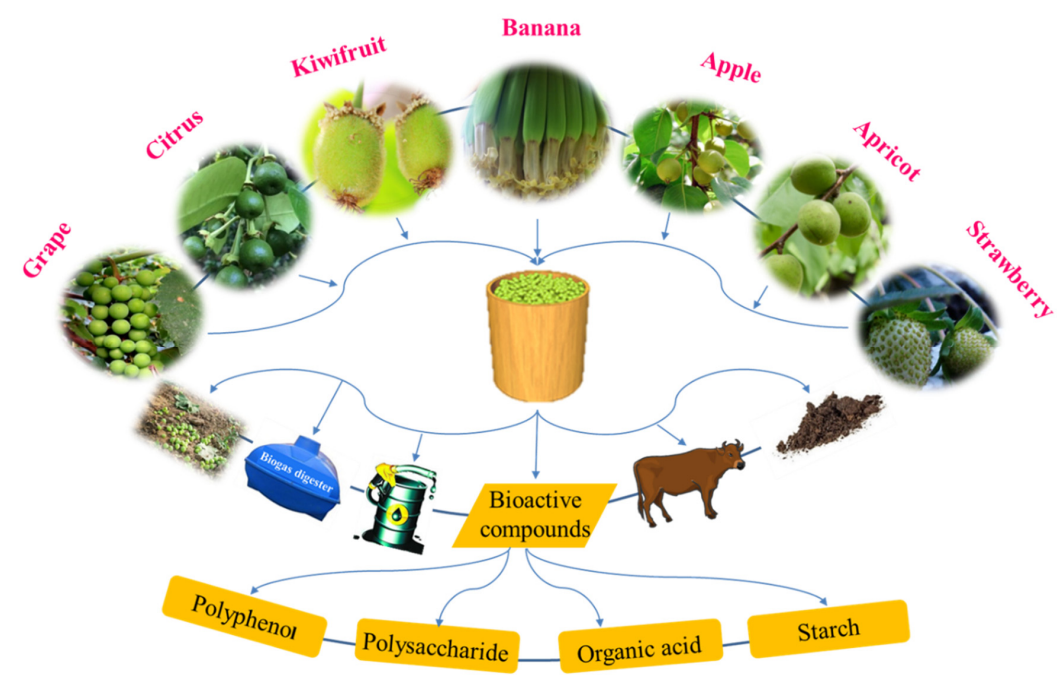

Figure 2. Utilization of thinned unripe fruit.

Thinned unripe fruits obtained from horticultural crops are rich in various active substances. However, traditional utilization was not employed by farmers, and this may detrimentally impact the biological and physico-chemical components of orchard soils. Therefore, the present review summarized the bioactive compounds contained in discarded unripe fruits, the beneficial health effects derived from the utilization of these bioactive substances, and methods for obtaining these compounds from thinned unripe fruits. After that, we roughly calculated the costs and benefits of obtaining bioactive compounds from discarded unripe fruits. This review has concluded and summarized the development and utilization of agricultural resources such as thinned unripe fruits from horticultural crops, and proposes issues for future research directions.

\section{Bioactive Compounds from Thinned Unripe Fruits}

\subsection{Phenolic Compounds}

During the growth and development of horticultural crops, the content of phenolic compounds in fruits decreases as fruit weight continues to increase because these compounds are mostly synthetized in fruit skins. Thereby, phenolic compound content in some unripe fruits is higher than in mature fruits [34], this has been confirmed in multiple reports, for example for grapes [35], apples [36], kiwifruits [37], and pomegranates [38]. Details are shown in Table 1.

During the growth and development of unripe fruits in certain fruit species, the content and profile of phenolic compounds are strongly affected by multiple factors. Labbé et al. [38] researched the differences in phenolic compound content in different ripening stages of pomegranate juices obtained from Wonderful, Chaca, and Codpa varieties. The author reported that the phenolic compound contents of pomegranate juices did not significantly differ between the different stages of ripening. However, significant differences were found between the different pomegranate varieties assessed. Interestingly, similar results were found in the study of strawberry. The difference in total phenolic content between the unripe and the ripe fruits was small, and the difference in total flavonoid content was significantly higher than in total phenolic content. The anthocyanin content of ripe fruits is significantly higher than that of unripe fruits, by up to 6 folds [39]. These details are shown in Table 1. 
Table 1. Comparison of total phenol content in unripe and mature fruits.

\begin{tabular}{|c|c|c|c|c|c|}
\hline \multirow{2}{*}{$\begin{array}{l}\text { Unripe } \\
\text { Fruits }\end{array}$} & \multirow{2}{*}{ Cultivars } & \multirow{2}{*}{$\begin{array}{c}\text { Maturity } \\
\text { Stages }\end{array}$} & \multicolumn{2}{|c|}{ Total Phenol Content } & \multirow{2}{*}{ Reference } \\
\hline & & & Unripe & Ripe & \\
\hline Grape & $\begin{array}{c}\text { Müller- } \\
\text { Thurgau, } \\
\text { Pinot Blanc, } \\
\text { Sauvignon, } \\
\text { Muscat } \\
\text { Ottonel }\end{array}$ & $\begin{array}{l}40 \text { days after } \\
\text { flowers }\end{array}$ & $5000 \mathrm{mg} / \mathrm{L}$ & $104 \mathrm{mg} / \mathrm{L}$ & [35] \\
\hline Apple & Fuji & $\begin{array}{c}25 \text { days after } \\
\text { full bloom } \\
\text { day }\end{array}$ & $360 \mathrm{mg} / 100 \mathrm{~g}$ & $40 \mathrm{mg} / 100 \mathrm{~g}$ & {$[36]$} \\
\hline Kiwifruit & $\begin{array}{l}\text { Zesy002, } \\
\text { Zesy004, } \\
\text { Hayward }\end{array}$ & $\begin{array}{l}20 \text { days after } \\
\text { fruit set }\end{array}$ & $71.67 \mathrm{mg} / 100 \mathrm{~g}$ & $9.05 \mathrm{mg} / 100 \mathrm{~g}$ & {$[37]$} \\
\hline Pomegranate & $\begin{array}{l}\text { Wonderful } \\
\text { Chaca } \\
\text { Codpa }\end{array}$ & - & $\begin{array}{l}1300 \mathrm{mg} / \mathrm{L} \\
1850 \mathrm{mg} / \mathrm{L} \\
1700 \mathrm{mg} / \mathrm{L}\end{array}$ & $\begin{array}{l}1910 \mathrm{mg} / \mathrm{L} \\
2130 \mathrm{mg} / \mathrm{L} \\
1610 \mathrm{mg} / \mathrm{L}\end{array}$ & [38] \\
\hline $\begin{array}{c}\text { Sweet } \\
\text { Orange Peels }\end{array}$ & Navel variety & $\begin{array}{l}\text { physiologically } \\
\text { matured with } \\
\text { green peel }\end{array}$ & $5.27 \mathrm{mg} / 100 \mathrm{~g}$ & $9.40 \mathrm{mg} / 100 \mathrm{~g}$ & {$[40]$} \\
\hline
\end{tabular}

As mentioned above, phenolic compounds is a generic term that contains multiple hydroxyphenol compounds. Therefore, the composition of phenolic compounds is very complex, and their value does not always depend on total phenol content. Several researchers studied the phenolic composition of different unripe fruits in depth.

Bagheri et al. [41] detected seven phenolic compounds in unripe grape juices including rutin, gallic acid, hydroxybenzoic acid, syringic acid, $p$-coumaric acid, quercetin, and resveratrol. Redondo et al. [42] studied the content of monomeric phenols in six types of unripe stone fruits, namely apricots, cherries, peaches, peaches, plums, and nectarines. Monomeric phenols were rich in these by-products, and the main phenolic group analyzed included proanthocyanidins and quercetin 3-rutinoside. Salces et al. [43] and Sun et al. [44] detected multifarious phenolic compounds in unripe apples, Nakashima et al. [45] isolated 11 types of tetrameric procyanidins from unripe apples, and the detailed structural diversity was determined. Sun et al. [46] identified and individually quantified 102 individual polyphenols grouped in five major classes of phenolic compounds such as phenolic acids, phenol glycosides, flavanols and flavone alcohols, using ultra-performance liquid chromatography coupled with electrospray ionization triple quadrupole mass spectrometry (UPLC-Q TRAP-MS/MS) in thinned unripe pears. Other researchers detected a variety of monomeric phenolic compounds in unripe fruits such as pomegranate, kiwi, sweet orange peels, chinotto citrus and raspberry $[19,37,40,47,48]$, as is shown in Table 2 . 
Table 2. Phenolic compounds detected in unripe fruits.

\begin{tabular}{|c|c|c|c|c|c|c|c|c|c|}
\hline \multirow{2}{*}{$\begin{array}{l}\text { Unripe } \\
\text { Fruits }\end{array}$} & \multirow{2}{*}{ Cultivars } & \multirow{2}{*}{$\begin{array}{c}\text { Maturity } \\
\text { Stages }\end{array}$} & \multicolumn{6}{|c|}{ Mono-Phenol Component } & \multirow{2}{*}{ Reference } \\
\hline & & & Phenolic Acids & Flavanols & Flavanones & Flavonols & Stilbenes & Others & \\
\hline Apricots & Pink Cot & $\begin{array}{l}42 \text { and } \\
48 \text { days } \\
\text { after full } \\
\text { bloom }\end{array}$ & $\begin{array}{c}\text { Neochlorogenic acid, } \\
\text { chlorogenic acid, } \\
\text { 4-p-coumaroylquinic } \\
\text { acid, 4-caffeoylquinic } \\
\text { acid, 3-feruloylquinic } \\
\text { acid, and } \\
\text { 3-p-coumaroylquinic } \\
\text { acid }\end{array}$ & Proanthocyanidins & $\begin{array}{l}\text { Quercetin-3- } \\
\text { O-rutinoside } \\
\text { and } \\
\text { kaempherol- } \\
\text { 3-O- } \\
\text { rutinoside }\end{array}$ & - & - & - & \multirow{4}{*}{ [42] } \\
\hline Cherries & $13 S-20-09$ & $\begin{array}{l}42 \text { and } \\
48 \text { days } \\
\text { after full } \\
\text { bloom }\end{array}$ & $\begin{array}{c}\text { Neochlorogenic acid, } \\
\text { chlorogenic acid, } \\
\text { isochlorogenic acid, } \\
\text { 4-p-coumaroylquinic } \\
\text { acid, 4-caffeoylquinic } \\
\text { acid, 3-feruloylquinic } \\
\text { acid, and } \\
\text { 3-p-coumaroylquinic } \\
\text { acid }\end{array}$ & Proanthocyanidins & $\begin{array}{l}\text { Quercetin-3- } \\
\text { O-rutinoside } \\
\text { and } \\
\text { kaempherol- } \\
\text { 3-O- } \\
\text { rutinoside }\end{array}$ & - & - & - & \\
\hline Peaches & $\begin{array}{l}\text { UFO-3, Royal } \\
\text { Glory, Laura }\end{array}$ & $\begin{array}{l}42 \text { and } \\
48 \text { days } \\
\text { after full } \\
\text { bloom }\end{array}$ & $\begin{array}{c}\text { Neochlorogenic acid, } \\
\text { chlorogenic acid, } \\
\text { isochlorogenic acid, } \\
\text { 4- } p \text {-coumaroylquinic } \\
\text { acid, 4-caffeoylquinic } \\
\text { acid, 3-feruloylquinic } \\
\text { acid, and } \\
\text { 3-p-coumaroylquinic } \\
\text { acid }\end{array}$ & Proanthocyanidins & $\begin{array}{l}\text { Quercetin-3- } \\
\text { O-rutinoside, } \\
\text { quercetin-3- } \\
\text { O-hexoside, } \\
\text { kaempherol- } \\
\text { 3-O- } \\
\text { hexoside, } \\
\text { and } \\
\text { kaempherol- } \\
\text { 3-O- } \\
\text { rutinoside }\end{array}$ & - & - & & \\
\hline Plums & Tolosa & $\begin{array}{l}42 \text { and } \\
48 \text { days } \\
\text { after full } \\
\text { bloom }\end{array}$ & $\begin{array}{c}\text { Neochlorogenic acid, } \\
\text { chlorogenic acid, } \\
\text { Isochlorogenic acid, } \\
\text { 4- } p \text {-coumaroylquinic } \\
\text { acid, 4-caffeoylquinic } \\
\text { acid, 3-feruloylquinic } \\
\text { acid, and } \\
\text { 3-p-coumaroylquinic } \\
\text { acid }\end{array}$ & Proanthocyanidins & $\begin{array}{l}\text { Quercetin-3- } \\
\text { O-rutinoside }\end{array}$ & - & - & - & \\
\hline Grape & $\begin{array}{l}\text { Thompson } \\
\text { Seedless }\end{array}$ & - & $\begin{array}{l}\text { Ggallic acid, benzoic } \\
\text { acid, hydroxybenzoic } \\
\text { acid, syringic acid, } \\
\text { and } p \text {-coumaric acid }\end{array}$ & $\longrightarrow$ & $\begin{array}{l}\text { Quercetin } \\
\text { and rutin }\end{array}$ & - & Resveratrol & - & [41] \\
\hline Apple & $\begin{array}{c}\text { Fuji, Nagafu } \\
2\end{array}$ & $\begin{array}{l}30 \text { days } \\
\text { after blos- } \\
\text { soming }\end{array}$ & $\begin{array}{l}\text { 5-Caffeoylquinic acid, } \\
\text { 4- } p \text {-coumarylquinic } \\
\text { acid, chlorogenic acid, } \\
\text { caffeic acid, and } \\
\text { phenylalanine ester }\end{array}$ & $\begin{array}{l}\text { (+)-Catechin, } \\
\text { (-)-epicatechin, } \\
\text { and procyanidin } \\
\text { B2 }\end{array}$ & $\begin{array}{c}\text { Rutin, } \\
\text { quercetin } \\
\text { quercetin-3- } \\
\text { O- } \\
\text { galactoside, } \\
\text { quercetin-3- } \\
\text { O- } \\
\text { rhamnoside, } \\
\text { isoquercetin, } \\
\text { and } \\
\text { quercetin }\end{array}$ & $\begin{array}{l}\text { Phloretin- } \\
2^{\prime}-O- \\
\text { xyloglucoside, } \\
\text { hydrox- } \\
\text { yphospho- } \\
\text { lipid } \\
\text { monogly- } \\
\text { coside, } \\
\text { hydroxy- } \\
\text { chrometin } \\
\text { diglyco- } \\
\text { side, and } \\
\text { hyperoside }\end{array}$ & - & - & {$[44]$} \\
\hline Pomegranate & $\begin{array}{c}\text { Borde de } \\
\text { Albatera 1, } \\
\text { PiñónTierno } \\
\text { deOjós } \\
\text { PiñónTierno } \\
\text { deOjós5, } \\
\text { Mollar de } \\
\text { Elche 14 et al. } \\
\text { (all of 9) }\end{array}$ & $\begin{array}{l}\text { Middle of } \\
\text { June to the } \\
\text { first week } \\
\text { of July } \\
\text { (Orihuela, } \\
\text { Alicante, } \\
\text { Spain) }\end{array}$ & - & $\begin{array}{l}\text { Ellagic tannin, } \\
\text { gallic acyl- } \\
\text { hexahydroxy, } \\
\text { dibenzoyl- } \\
\text { hexanoside, and } \\
\text { gallic } \\
\text { acyl-glucoside }\end{array}$ & - & - & - & - & [19] \\
\hline Kiwifruit & $\begin{array}{l}\text { Zesy002, } \\
\text { Zesy004, } \\
\text { Hayward }\end{array}$ & $\begin{array}{l}20 \text { days } \\
\text { after fruit } \\
\text { set }\end{array}$ & $\begin{array}{l}\text { Gallic acid, } \\
\text { protocatechuic acid, } \\
\text { chlorogenic acid, } \\
\text { caffeic acid, vanillic } \\
\text { acid, } p \text {-Coumaric acid, } \\
\text { and ferulic acid }\end{array}$ & $\begin{array}{l}\text { Catechin } \\
\text { epigallocatechin } \\
\text { gallate, and } \\
\text { epicatechin }\end{array}$ & $\begin{array}{l}\text { Rutin, } \\
\text { quercitrin, } \\
\text { and } \\
\text { quercetin } \\
\text { hyperoside }\end{array}$ & - & - & - & [37] \\
\hline
\end{tabular}


Table 2. Cont.

\begin{tabular}{|c|c|c|c|c|c|c|c|c|c|}
\hline \multirow{2}{*}{$\begin{array}{l}\text { Unripe } \\
\text { Fruits }\end{array}$} & \multirow{2}{*}{ Cultivars } & \multirow{2}{*}{$\begin{array}{l}\text { Maturity } \\
\text { Stages }\end{array}$} & \multicolumn{6}{|c|}{ Mono-Phenol Component } & \multirow{2}{*}{ Reference } \\
\hline & & & Phenolic Acids & Flavanols & Flavanones & Flavonols & Stilbenes & Others & \\
\hline Pears & $\begin{array}{c}\text { Fengshui, } \\
\text { Cuiguan, } \\
\text { Dangshansuli } \\
\text { et al. (all of } \\
\text { 10) }\end{array}$ & $\begin{array}{l}20 \text { days } \\
\text { after full } \\
\text { bloom }\end{array}$ & $\begin{array}{l}\text { Quinic acid, cinnamic } \\
\text { acid isomer, } \\
\text { chlorogenic acid, } \\
\text { 1-O-caffeoylquinic } \\
\text { acid, 4- } p \text { - } \\
\text { coumaroylquinic acid, } \\
\text { caffeoylshikimic acid, } \\
\text { 3-O-feruloylquinic } \\
\text { acid, caffeoyl- } \\
\text { malonyl-methylcitric } \\
\text { acid, isochlorogenic } \\
\text { acid A, and } p \text { - } \\
\text { coumaroylcaffeoylquinic } \\
\text { acid }\end{array}$ & $\begin{array}{l}\text { (+) -Catechin, } \\
(-) \text {-epicatechin, } \\
\text { and procyanidin } \\
\text { dimer }\end{array}$ & - & - & $\longrightarrow$ & $\begin{array}{l}\text { Arbutin, caf- } \\
\text { feoylarbutin, } \\
\text { p-coumaroy } \\
\text { larbutin, and } \\
p \text {-coumaroy } \\
\text { larbutin }\end{array}$ & [46] \\
\hline Orange & Navel variety & $\begin{array}{l}\text { Physiologically } \\
\text { matured } \\
\text { with green } \\
\text { peel }\end{array}$ & Caffeic acid & $\begin{array}{l}\text { Catechin and } \\
\text { epicatechin }\end{array}$ & $\begin{array}{c}\text { Rutin, } \\
\text { quercitrin, } \\
\text { quercetin, } \\
\text { naringin, } \\
\text { kaempferol, } \\
\text { and luteolin } \\
\end{array}$ & - & - & - & {$[40]$} \\
\hline Raspberry & $\begin{array}{c}\text { Rubus chingii } \\
\mathrm{Hu}\end{array}$ & $\begin{array}{l}\text { Green } \\
\text { fruit stage }\end{array}$ & Ellagic acid & $\begin{array}{l}\text { (+)-Catechin, } \\
\text { (-)-epicatechin, } \\
\text { and proantho- } \\
\text { cyanidin } \\
\text { B1 }\end{array}$ & $\begin{array}{c}\text { Rutin, } \\
\text { quercetin, } \\
\text { kaempferol, } \\
\text { quercetin-3- } \\
O- \\
\text { glucuronide, } \\
\text { kaempferol- } \\
3-O- \\
\text { rutinoside, } \\
\text { and } \\
\text { kaempferol- } \\
3-O- \\
\text { glucoside }\end{array}$ & - & - & - & [48] \\
\hline
\end{tabular}

_. not mentioned in the literature.

\subsection{Non-Phenolic Bioactive Compounds}

\subsubsection{Organic Acids}

Unripe fruits contain a wide range of many other components with high bioactivity, including organic acids and polysaccharides. The acidity levels in unripe fruits are extremely high. Jančářová et al. [35] studied the change in acidity during the growth of different grape varieties. These authors reported that the titratable acid content of each grape variety increased (up to $40 \mathrm{~g} / \mathrm{L}$ ) initially, and the content of titratable acid decreased considerably as the fruit gradually ripened (up to $3.8 \mathrm{~g} / \mathrm{L}$ ). The content of titratable acid decreased rapidly as it matured until it became constant. In another report, de Matos et al. [49] produced "Verjuice" obtained from six unripe grapevine varieties at three different dates. These results reported that the "Verjuice" contained acidity levels that from 17.4 to $40.5 \mathrm{~g} / \mathrm{L}$. The malic acid and tartaric acid content in this juice varied from 10.9 to $30.4 \mathrm{~g} / \mathrm{L}$ and from 5.5 to $14.0 \mathrm{~g} / \mathrm{L}$, respectively. The organic acid content in unripe peaches from Nagasawa hakuho and Mibaekdo varieties (Prunis persica) and Japanese apricots of the Backaha variety (Prunus mume) was also studied. These authors detected oxalic acid, tartaric acid, malic acid, and lactic acid in the three studied varieties. The contents of these organic acids in the fruits collected from the unripe peach varieties reached 612.8, 301.0, 495.5 , and $314.7 \mathrm{mg} / 100 \mathrm{~g}$ of dry weight, respectively [50]. The main organic acids in strawberries are malic acid and citric acid, and the content of citric acid is generally higher than that of malic acid. With the increase in maturity, the content of organic acid gradually decreases [39].

\subsubsection{Polysaccharides}

Apart from polyphenols, the polysaccharides obtained in unripe fruits also showed antioxidant and scavenging effects of free radicals, which may prevent and treat some chronic diseases $[51,52]$. To study the mechanical structure of plant cell walls, MacDougall et al. [53] used a gelation technique and found that pectin polysaccharides were the main component of cell walls. Based on this finding, the authors characterized tomato pectin 
polysaccharides and demonstrated that these compounds were primarily composed of rhamnogalacturonan. Galactose and arabinose are main polysaccharide units found in unripe apples, while mannose, rhamnose, glucuronic acid, galacturonic acid, glucose, and xylose contribute small amounts to its composition [54]. In addition, it was shown that the peels of unripe banana fruits contained rhamnose, trehalose, arabinose, xylose, mannose, galactose, glucose and uronic acid [55], as shown in Table 3.

Table 3. Organic acids and monosaccharides in unripe fruits.

\begin{tabular}{|c|c|c|c|c|c|}
\hline $\begin{array}{c}\text { Active } \\
\text { Components }\end{array}$ & $\begin{array}{l}\text { Unripe } \\
\text { Fruits }\end{array}$ & Cultivars & $\begin{array}{l}\text { Maturity } \\
\text { Stages }\end{array}$ & $\begin{array}{c}\text { Component } \\
\text { Characterization }\end{array}$ & Reference \\
\hline \multirow{3}{*}{ Organic acids } & Grape & $\begin{array}{c}\text { Glera, } \\
\text { Chardonnay, } \\
\text { Sauvignon } \\
\text { Blanc, Merlot, } \\
\text { Cabernet } \\
\text { Franc and } \\
\text { Cabernet } \\
\text { sauvignon }\end{array}$ & $\begin{array}{l}\text { Bunch } \\
\text { closure }\end{array}$ & $\begin{array}{l}\text { Tartaric acid and } \\
\text { malic acid }\end{array}$ & [49] \\
\hline & Peach & $\begin{array}{l}\text { Mibaekdo } \\
\text { and } \\
\text { Nagasawa } \\
\text { Hakuho }\end{array}$ & $\begin{array}{c}\text { 30-35 days } \\
\text { after } \\
\text { flowers }\end{array}$ & $\begin{array}{c}\text { Oxalic acid, } \\
\text { tartaric acid, } \\
\text { malic acid, and } \\
\text { lactic acid }\end{array}$ & [50] \\
\hline & Strawberry & $\begin{array}{l}\text { Seolhyang, } \\
\text { Janghee, and } \\
\text { Maehyang }\end{array}$ & $\begin{array}{l}50 \% \text { of fruit } \\
\text { surface } \\
\text { turns into } \\
\text { red color }\end{array}$ & $\begin{array}{l}\text { Malic acid and } \\
\text { citric acid }\end{array}$ & [39] \\
\hline \multirow{5}{*}{ Monosaccharide } & Grape & $\begin{array}{c}\text { Glera, } \\
\text { Chardonnay, } \\
\text { Sauvignon } \\
\text { Blanc, Merlot, } \\
\text { Cabernet } \\
\text { Franc and } \\
\text { Cabernet } \\
\text { Sauvignon }\end{array}$ & $\begin{array}{l}\text { Bunch } \\
\text { closure }\end{array}$ & $\begin{array}{l}\text { Glucose and } \\
\text { fructose }\end{array}$ & [49] \\
\hline & Tomato & - & - & Rhamnogalacturonan & [53] \\
\hline & Apple & - & $\begin{array}{l}30 \text { days } \\
\text { after } \\
\text { blossom }\end{array}$ & $\begin{array}{c}\text { Galactose, } \\
\text { arabinose, } \\
\text { mannose, } \\
\text { rhamnose, } \\
\text { glucuronic acid, } \\
\text { galacturonic acid, } \\
\text { glucose, and } \\
\text { xylose }\end{array}$ & [54] \\
\hline & Banana & $\begin{array}{c}\text { Musa } \\
\text { sapientum }\end{array}$ & - & $\begin{array}{c}\text { Rhamnose, } \\
\text { trehalose, } \\
\text { arabinose, xylose, } \\
\text { mannose, } \\
\text { galactose, glucose, } \\
\text { and uronic acid }\end{array}$ & [55] \\
\hline & Strawberry & $\begin{array}{l}\text { Seolhyang, } \\
\text { Janghee, and } \\
\text { Maehyang }\end{array}$ & $\begin{array}{l}50 \% \text { of fruit } \\
\text { surface } \\
\text { turns into } \\
\text { red color }\end{array}$ & $\begin{array}{l}\text { Fructose, glucose, } \\
\text { and sucrose }\end{array}$ & [39] \\
\hline
\end{tabular}

—: not mentioned in the literature.

Bananas are rich in starch, and starch content decreases significantly during maturity from 63.3 to $26.0 \mathrm{~g} / 100 \mathrm{~g}$ [56]. Therefore, thinned unripe bananas have interesting potential 
for development as agricultural waste (Table 4). Espinosa-Solis et al. [57] studied the starches of unripe banana and mango fruits and compared the starch in these two unripe fruits to corn starch. The results showed that the content of amylose in unripe banana and mango fruits was higher than in corn. Moongngarm [58] showed that the powder extracted from banana fruits 105 days after banana flowering contained the most resistant starch, and it accounted for $48.9 \%$ of total starch. Menezes et al. [59] indicated that the content of resistant starch of unripe bananas reached $48.99 \mathrm{~g} / 100 \mathrm{~g}$ - with the exception of mango meat and mango nuts. Patiño-Rodríguez et al. [60] showed that the starch content of unripe mango kernels was $48.79 \mathrm{~g} / 100 \mathrm{~g}$. Starch is also the main component in kiwi fruit when it is commercially picked. Furthermore, unripe kiwi fruits are also an interesting potential source of starch for utilization. The starch content of the kiwi variety Gold3 reached 40\% 81 days after flowering and reached its highest starch content 137 days after flowering (58.45\%) [61].

Table 4. Starch content in unripe fruits.

\begin{tabular}{|c|c|c|c|c|c|c|}
\hline $\begin{array}{l}\text { Unripe } \\
\text { Fruits }\end{array}$ & Cultivars & $\begin{array}{l}\text { Maturity } \\
\text { Stages }\end{array}$ & $\begin{array}{c}\text { Apparent } \\
\text { Amylose } \\
\text { Content } \\
{[\%]}\end{array}$ & $\begin{array}{c}\mathbf{M}_{\mathrm{w}} \times 10^{8} \\
{[\mathrm{~g} / \mathrm{mol}]}\end{array}$ & $\mathbf{R}_{\mathbf{z}}[\mathrm{nm}]$ & Reference \\
\hline Bananas & Macho & - & 36.2 & $3.371 \pm 0.179$ & $267.10 \pm 5.515$ & [57] \\
\hline $\begin{array}{c}\text { Mango } \\
\text { meat }\end{array}$ & $\begin{array}{l}\text { Tommy } \\
\text { Atkins }\end{array}$ & - & 31.1 & $5.013 \pm 0.177$ & $297.85 \pm 1.202$ & [58] \\
\hline $\begin{array}{l}\text { Mango } \\
\text { nuts }\end{array}$ & - & - & 23.0 & - & - & \\
\hline \multirow{2}{*}{ Kiwifruit } & Hayward & $\begin{array}{l}45 \text { days } \\
\text { after } \\
\text { flowers }\end{array}$ & 10.0 & - & - & \multirow{2}{*}{ [61] } \\
\hline & Gold3 & $\begin{array}{l}53 \text { days } \\
\text { after } \\
\text { flowers }\end{array}$ & 15.4 & - & - & \\
\hline
\end{tabular}

Polyphenols, organic acids, monosaccharides, starch, and other compounds are abundant in thinned unripe fruits, and each component plays a unique role. To reasonably use and develop the maximum extent of these agriculture wastes, it is necessary to deepen our research and explore its potential value. The present research on unripe fruit compounds lay a theoretical foundation for the development of extraction methodologies and understand the functional role of each component.

\section{3. "High Added Value" of Bioactive Components from Thinned Unripe Fruits}

Many studies reported that the inclusion of more fruits in the diet is good for our health because it may reduce the chance of many chronic diseases, such as cardiovascular disease, cancer, obesity and diabetes (Figure 3) $[62,63]$. These beneficial effects are attributed to the fact that fruits contain several phytochemical components, and phenolic compounds account for a large proportion [64-69]. The second apart of this review describes the bioactive components contained in unripe fruits, which occur at higher concentrations than mature fruits. These results are interesting because unripe fruits are good for human health, and the management of unripe fruits shows the positive aspects of the revalorization of byproducts in favor of a circular economy. 


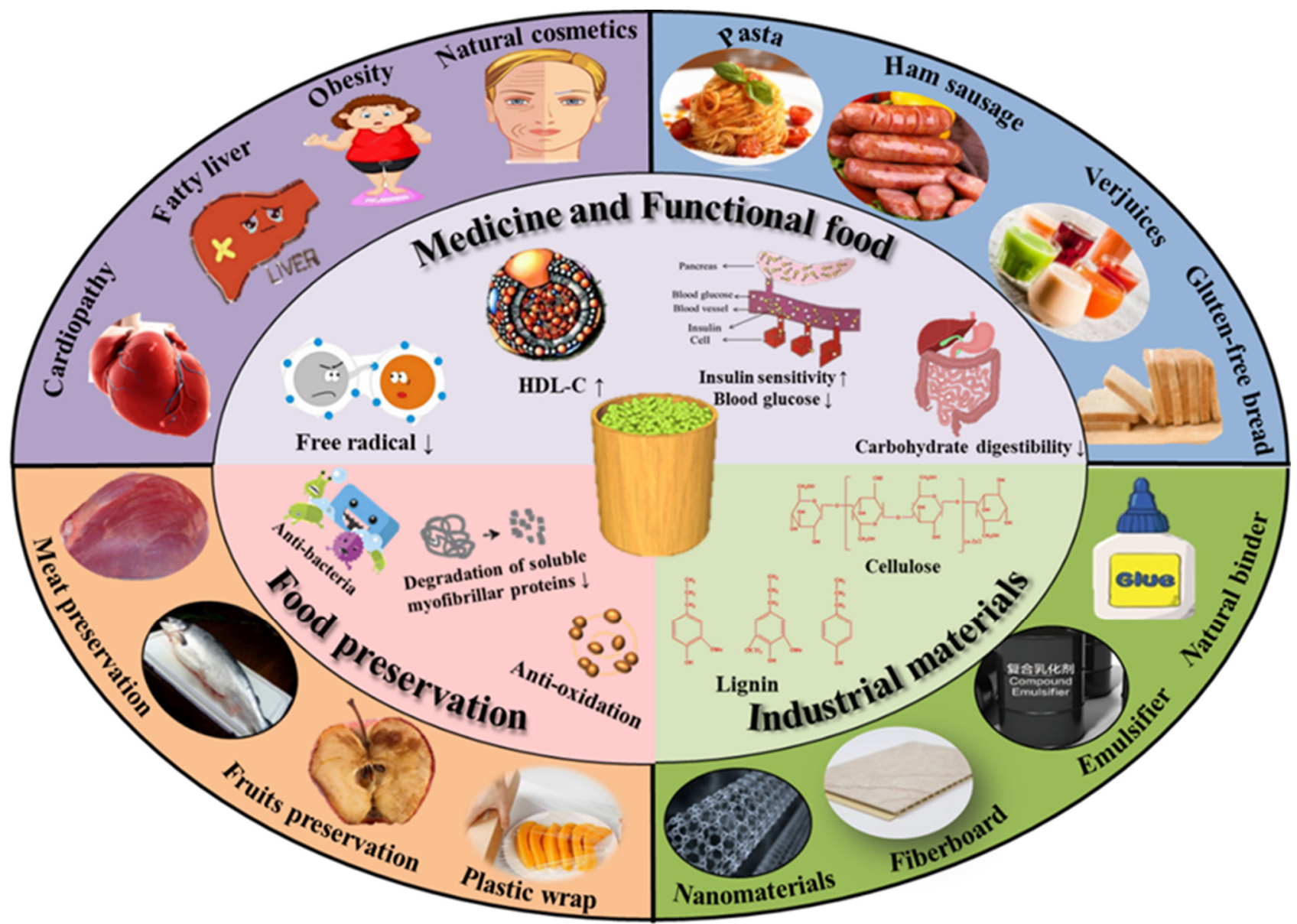

Figure 3. High added value of thinned unripe fruits (possible applications of unripe fruits in medicine, functional food, food preservation, and industrial materials).

\subsection{Utilization of Unripe Fruits for Crude Extract}

An extract from unripe kiwi fruits was obtained by Abe et al. [70] and may play a beneficial role in diabetes through its ability to regulate the adipocytes' differentiation and function; however, unripe Musa paradisiaca achieved the same effect because of its ability to adsorb blood sugar, and Bhinge et al. [71] verified this is greater for unripe than ripe and overripe fruit extracts. Some other studies showed that unripe apple pomace can be used as a functional food to achieve the same effect [72]. In addition, unripe grape juice consumption had a considerable effect on improving high-density lipoprotein (HDL-C) levels [31,73], and had important effects against food-borne pathogens such as Bacillus cereus, Escherichia coli, Listeria monocytogenes, Salmonella Typhimurium, and Staphylococcus aureus. Therefore, the juice from unripe grape contained antibacterial properties and could be considered a functional food as well [74]. Additionally, some researchers used unripe fruits for fresh fish feed, and the results showed a positive role of unripe fruits for feed [75]. However, beyond that, there is evidence that the extracts from unripe peaches and apples decreased the damage to the dermal-epidermal junction caused by UV-B radiation due to sun exposure $[76,77]$.

Bioactive compounds from unripe fruits are variable, and if we only study the various effects of the unripe fruits as a whole, then many impurities may be obtained from the extraction reactions. Therefore, it is possible that the functional components of the unripe fruits cannot be used in a targeted manner. The commercialization of bioactive compounds may improve the utilization rate of unripe fruits by farmers. Consequently, the extraction of these components still needs further research. Some researchers simply ex- 
tracted polyphenols, polysaccharides, organic acids, starches and other high-added-value components.

\subsection{Utilizations of Unripe Fruits for Their Phenolic Composition}

\subsubsection{Antioxidants}

During plant growth and reproduction, polyphenols have a protective effect against pathogenic bacteria and have important antioxidant activities and their consumption is beneficial to human health $[78,79]$. These beneficial effects are primarily related to their antiinflammatory activity [80], a lower incidence of a wide number of cancers and diabetes [81] and antithrombotic and heart protection activities [82,83]. Among all of the beneficial effects, antioxidant capacity is the most extensively studied. Phenolic compounds have benzene rings containing hydroxyl groups. Different polyphenol groups make diverse contributions to the antioxidant activity [84]. Phenolic composition plays a very important role in antioxidant capacity rather than phenolic content. Among them, proanthocyanidins B1, (-)-epicatechin and proanthocyanidins B2 had higher antioxidative activities than other polyphenols $[85,86]$. In other words, in terms of antioxidants, different polyphenolic compounds play different roles and the coordination between different polyphenols may determine the total antioxidant activity [87]. Therefore, it is still necessary to further study whether the main reasons for the high antioxidant activity of unripe fruits are total phenolic content, monomer phenolic composition, or the interaction between them.

Yue et al. [88] extracted phenolic compounds from unripe apple fruits and determined the antioxidant activity by evaluating 2,2-diphenyl-1-picrylhydrazyl (DPPH)-scavenging activity and the inhibition of lipid peroxidation. These authors indicated that the antioxidant activity against DPPH of the extracted polyphenols from unripe apples was higher than ripe fruits, and the polyphenols also effectively inhibited lipid peroxidation, with greater inhibitory activity than the lipophilic organic antioxidant compound butylated hydroxytoluene (BHT). Similarly, the antioxidant activity of polyphenol extracts from unripe stone fruits such as apricot, cherry, peach, plum, and nectarine, as well as from unripe grape fruits, was higher than from ripe fruits [42,89]. This suggests that many unripe fruits are potential antioxidants.

\subsubsection{Natural Cosmetics}

With the continued research on polyphenols from unripe fruits, researchers are discovering other various study topics and different application aspects in addition to the antioxidant activity of unripe fruit polyphenols. Choi et al. [90] showed that polyphenol extracts of small-sized apples had a better inhibitory effect on tyrosinase than that of large apples. These results are interesting because thinned fruits are smaller and have a higher skin-to-fruit ratio than mature fruits, which controls the production of melanin. The authors elucidated that quercetin in the polyphenol extracts was closely related to the inhibition of tyrosinase. Unripe grapes can also counteract enzymatic browning, achieving the effect of natural skin whitening, cinnamic acid analogs including caffeic acid, coumaric acid and ferulic acid, suggesting that caffeic acid affects the tyrosinase inhibitory effect more than coumaric acid and ferulic acid. Early studies showed that polyphenolic compounds with hydroxyl or methoxy groups at the 4-position of cinnamic acid derivatives were potent inhibitors of tyrosinase [91]. In the same way, polyphenol extracts from peach juveniles also have the same utilization value [34,92]. Thus, the use of young fruit in cosmetic formulations should be a good choice. Sun et al. [44] found that porcine pancreas $\alpha$-amylase (PPA) was inhibited by nine monomer phenols from unripe apples using in vitro essays, and tannic acid, chlorogenic acid and caffeic acid showed higher inhibition.

\subsubsection{Food Preservation}

It is precisely because polyphenols from unripe fruits have antioxidant activities and inhibitory effects on many enzymes that these biological properties give unripe fruit polyphenols a varied range of utilization. Sun et al. [93] studied the effect of polyphenols 
obtained from unripe apples on grass carp (Ctenopharyngodon idellus) surimi quality during cold storage at $4{ }^{\circ} \mathrm{C}$. The research displayed that adding polyphenols from unripe apples to grass carp may have a dramatic effect on slowing down lipid oxidation and lead to a degradation of soluble myofibrillar proteins. Other interesting results from this report are that polyphenols from unripe apples also protected the functional characteristics of grass carp during the refrigeration process. They also increased the surface hydrophobicity and reduced their emulsification activity and stability. Among the studied phenolic compounds, chlorogenic acid played a major role in the aforementioned beneficial effects.

\subsubsection{Biofilms}

Owing to the antioxidant effect of polyphenols from unripe apples, a positive effect on the preservation of food and significant improvement in the antioxidant and bacteriostatic abilities of the chitosan film were observed. The author also tried to add polyphenols from unripe apples to edible packaging materials. The thickness, density, swelling, solubility, and opacity of the bioactive chitosan film were increased because of the addition of polyphenols extracted from unripe apples, but at the same time, there are some negative effects on the film, such as the water content, moisture permeability, and mechanical properties [94]. Nisar et al. [95] observed similar results when combining polyphenols from unripe apples with citrus pectin to make a biodegradable film. These authors suggested that polyphenols obtained from unripe apples had great potential in the production of thin biofilms. Similarly, unripe bananas and grapes also have antibacterial abilities. Chitosan-unripe banana peel films had an inhibitory effect on Staphylococcus aureus and Escherichia coli, which are generally present in wounds and showed the potential application for wound bacteriostasis [96]. Additionally, unripe grapes inhibited the fungal activity of Candida spp. and other dermatophytes [97].

\subsubsection{Functional Foods and Additives}

Unripe fruits are rich in polyphenols and good for human health, so their use as functional foods has become more popular in recent years. The transformation of polyphenols from unripe apples into functional foods is a very interesting topic currently, and it has promoted the development and utilization of discarded unripe fruits. Functional food such as industrially processed or natural food that when consumed regularly at efficacious levels has potentially positive effects on health beyond basic nutrition [98]. Verjuice and sour grape sauces produced from grape unripe fruits have important antioxidant activity and have extended the shelf life of foods. These characteristics result in antibacterial effects against different food-borne pathogens such as Escherichia coli, Listeria monocytogenes, Salmonella typhimurium and Staphylococcus aureus [99]. Therefore, unripe grape may be used as flavoring and acidifying agents, and may even be considered natural sanitizers. In light of food safety and human health, unripe grape products have the potential to replace chemical additives and preservatives, which may be related to the high total phenol and flavonoid contents [100]. However, the content of unripe grape used in the food industry is decided by various factors, such as processing conditions, variety, edaphoclimatic conditions of the growing area, and maturity at harvest, so there are still many unbroken difficulties in the industrialization of unripe grape products.

The development of unripe fruits has a very positive effect on human health and the environment. Although polyphenols from unripe fruits may be used as functional foods, the taste of polyphenolic substances in unripe fruit is bitter, there are negative effects on the sensory quality of food. The addition of unripe fruits may also change the composition of polyphenolic substances. Bucalossi et al. [101] investigated how to make food products containing polyphenols from unripe fruits acceptable, in terms of sensory characteristics, to consumers and how to maximize the effect of polyphenols. An extract from thinned unripe grapes was used to fortify three plant-based food models: (i) beetroot purée (carbohydrates/acidic ph/sweet), (ii) pea purée (proteins/neutral ph/sweet) and (iii) potato purée (starch/neutral ph). In terms of both sensory quality and food functionality, 
beetroot purée was more suitable for offsetting the negative sensation induced by the polyphenols from unripe grapes.

\subsection{Utilizations of Unripe Fruits Due to Non-Phenolic Bioactive Compounds}

In unripe fruits, with the exception of polyphenols, there are many other bioactive compounds in unripe fruits with high value added, which also have antioxidant activity, free radical-scavenging activity, and many other useful functions.

\subsubsection{Health Profits}

Unripe banana fruits contain a large amount of starch, rich in carbohydrates that are not digested and absorbed by the human stomach and small intestine. Due to the presence of resistant starch, there is a low response in postprandial blood glucose. Long-term diet intervention on the body increases insulin sensitivity, and in vitro colonic fermentation produces more short-chain fatty acids. Unripe bananas have significant effects in improving diabetes, obesity and other diseases [102]. Sardá et al. [103] showed that healthy volunteers maintain blood sugar homeostasis, increased insulin sensitivity and satiety, and reduced hunger and daily energy intake when eating unripe banana powder three times per week for six weeks. Similarly, Rosado et al. [104] showed that the consumption of resistant starch from unripe bananas in mice allowed lower gains in body mass than mice consuming non-supplemented starch. The accumulation of liver fat was less in mice receiving unripe bananas than the control non-supplemented mice and the liver was protected by the reduced production of short-chain fatty acids due to the addition of at least $15 \%$ unripe bananas in the diet.

Many researchers characterized the polysaccharides of unripe apples and some research examined its development in recent years due to its potential functional value. Dou et al. [54] characterized the polysaccharides of unripe apples, and polysaccharides extracted from unripe fruits possessed antioxidant capacity. Polysaccharides were obtained from unripe apples by Chen et al. [105] and shown to possess the ability successfully reduce obesity-related liver metabolic disorders via activation of the respiratory function of liver mitochondria in mice.

\subsubsection{Functional Foods and Additives}

Unripe fruits contain important organic acids, and it is possible to produce unripe fruit juices or powders as natural acidifier condiments [49]. Some starchy unripe fruits, such as banana, mango, and kiwi can be used as a substitute for flour or starch to make many functional foods. Castaño et al. [106] used unripe banana flour rather than wheat to produce gluten-free bread. Compared with wheat bread, gluten-free bread with $8 \%$ and $15 \%$ of banana flour resulted in higher fiber content and lower carbohydrate content, and the same results were found in Patiño-Rodríguez's [107] study. However, gluten-free products have a slightly different texture compared to gluten products, and taste will be defective. Incidentally, Aguirre [108] reported that the addition of hydrocolloids and pregelatinized starches such as hydroxypropyl methylcellulose and pregelatinized unripe banana flour improved the taste of gluten-free products. Moreover, other researchers replaced fat with unripe bananas to make ham sausages [109], pound cakes [110] and other foods, which reduced the use of fat and sugar. The revalorization of unripe bananas has allowed us to obtain healthier foods without affecting sensory characteristics.

\subsubsection{Ethanol Production}

Waghmare et al. [111] made a powder from unripe banana skin, and produced a $49.2 \%$ $w / w$ reduction in sugars by acid hydrolysis, and Saccharomyces cerevisiae was screened for ethanol conversion efficiency. On the basis of optimizing the conditions of fermentation, $35.5 \mathrm{~g} / \mathrm{L}$ ethanol was produced. In this condition, unripe banana peels were also a potential resource for ethanol production. 
Global warming is one of the greatest issues in the wine industry because wines have an increasingly high alcoholic content due to the high accumulation of soluble solids in berries. Certain studies showed that unripe grapes could be used to produce low-alcohol wines or reduce the alcohol content of the wine by mixing unripe grapes with grapes that had reached harvest maturity [112,113]. "Double harvest" is the technique that decreases the alcoholic content in wines and improves the acidity in a natural form. This technique also takes advantage of the grapes removed by cluster thinning [114]. In addition to reducing alcohol content, Fia et al. [115] also found that the addition of unripe grape fruit extracts to wine could play a role in protecting wine color during aging, and could be an interesting substitute for $\mathrm{SO}_{2}$ during wine ageing. Considering that unripe fruits lack phenolic maturity, and bring an excess of astringency and herbaceous aromas, Junior et al. [116] found that $S$. bacillaris can be used to increase glycerol content and malic acid degradation, thereby balancing the lack of palate fullness caused by low alcohol content and masking 'vegetative' odors.

\subsubsection{Industrial Materials}

Sucrose and glucose are the main sugars in unripe peach fruits, and citric acid is the main organic acid. Compared with mature fruits, unripe fruits have higher contents of organic acids and a lower sugar content than ripe fruits, which may be helpful to the formation of carbon materials [117]. For this reason, unripe fruit may be a good source of nanomaterials. For example, photoluminescent carbon dots (CDs) are a new class of nanoparticles with exceptional advantages, such as low toxicity, high chemical stability, good biocompatibility, excellent optical performance, and low photo bleaching, and have therefore received wide interest. At the same time, nitrogen-doped carbon dots (N-CDs) are also receiving interest due to highly enhanced photoluminescence $[25,118]$.

After unripe bananas were made into banana powder, Martínez et al. [119] produced a natural polymer based on 50\% thermoplastic unripe banana flour (TPF) mixed with metallocene-catalyzed polyethylene (mPE), which was a robust, elastic, and non-brittle material. With these characteristics, the blends were ideal for the design of biodegradable plastics. The shells of unripe coconuts are very rigid and contain a large amount of cellulose and lignin. Lignin from coconut husks may be used as a natural binder with high temperature and pressure. Based on these findings, a convenient and favorable technology was developed from coconut husks to produce high-strength-high-density panels without the addition of chemical binders. Junior et al. [120] reported that coir-based fiberboards may be applied to furniture, wallboards, floors, and coatings without the need to cut down trees. Unripe coconut husk as a raw material with potential for use in fiberboards without binders was examined. The results showed that coconut shell material played a crucial role in the production of fiberboards. Additionally, there were other studies also showing that polysaccharides from unripe apples had emulsification properties [32].

Based on the published research, the utilization of unripe fruits involves different fields such as medicine, food preservation, functional foods, industrial materials, and environmental care. Therefore, the use of unripe fruits at this stage is extremely important. Several wastes are produced during horticultural production and we must identify an economical method to recycle agricultural waste. The collection of bioactive components from unripe fruits is of wide importance, and one critical step is to maximize the value of their extraction using different methodologies, which is discussed in the following sections.

\section{Methods to Extract Bioactive Components from Thinned Unripe Fruits}

\subsection{Methods to Extract Phenolic Compounds}

It has been described above that unripe fruits are one source of polyphenolic compounds. According to many experiments, because of the important effects on human health and food preservation, polyphenols of unripe fruit may have the potential to replace traditional chemical inhibitors and preservatives. The development of polyphenols from unripe fruits would greatly impact environmental resources. Present extraction methods 
of phenolic compounds include solvent extraction [121], subcritical water extraction [122], microwave-assisted extraction [123] and enzyme extraction methods [124], but there is no large-scale extraction technology to extract polyphenols from unripe fruits. Therefore, the economic costs of this extraction are high. In addition, the instability of the polyphenols, due to their presence in bounded or polymerized forms, in fruits limits their extraction, purification and equipment technology [15]. In recent years, many scholars performed a series of studies on the role of polyphenols from unripe fruits and the pretreatment of unripe fruits, including solvent extraction, microwave-assisted extraction and enzyme extraction method are described as follow (Figure 4), which has laid a certain foundation for the extraction of polyphenols.
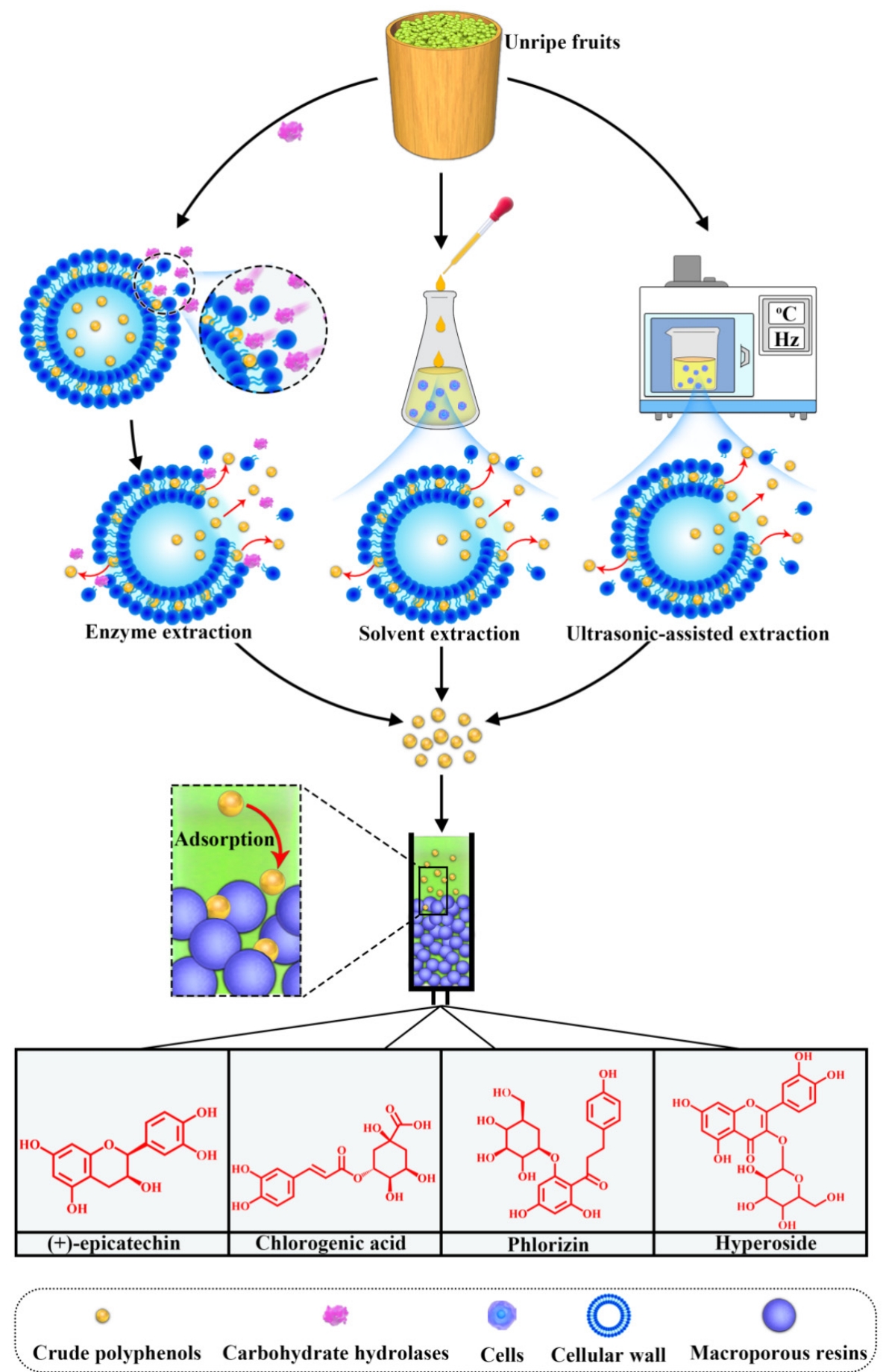

Figure 4. The methods of extracting polyphenol. 
To improve the extraction efficiency of plant polyphenols, years ago, researchers introduced carbohydrate hydrolases (such as pectinase, cellulase, hemicellulose, and glucanase) to release complex polyphenols from cell walls (Figure 4) [125-127]. Zheng et al. [128] showed how to increase the extraction of phenolic compounds from unripe apple fruits by selecting a carbohydrate hydrolase (Viscozyme ${ }^{\circledR}$ L). Subsequently, Zheng [124] enhanced the optimal conditions for the extraction of phenolic compounds from unripe apples, and the extraction rate of polyphenols was improved compared to Zheng et al. [128]. The total phenol and caffeic acid contents were approximately 2- and 13-fold higher than that of the control, respectively.

Shojaee-Aliabadi et al. [129] extracted polyphenols from unripe grapes using a solvent extraction method and an ethanol solution as the extractant agent and discussed the impact conditions such as extraction time, extraction temperature, and ethanol concentration, optimized by the response surface methodology. The results elucidated that the amounts of extracted polyphenols and the elimination of DPPH were significantly affected by the time, temperature, and ethanol concentration of the extraction. After conditional optimization, phenol extraction was improved. The extracted content of polyphenols was $0.39 \mathrm{~g} \mathrm{GAE} / 100 \mathrm{~g}$, and the amount of DPPH elimination was 91.01\%. Proanthocyanidins from unripe sapodilla (Manilkara zapota) fruits were also isolated using solvent extraction through gel filtration media (Sephadex LH-20) [130]. Yue et al. [88] obtained polyphenolic compounds from unripe apple fruits by ultrasonic-assisted extraction and studied the effects of ultrasonic power, extraction time, temperature, and ethanol concentration on total polyphenol yield by the response surface method. The results indicated that the total polyphenol yield was $13.26 \pm 0.56 \mathrm{mg}$ GAE/g. Several experiments showed that ultrasound-assisted extraction significantly improved the extraction rate of phenolic compounds, with important reductions in reaction times compared to solvent extract methodologies [41]. In recent years, Fia et al. [131] obtained bioactive compounds from unripe grape through a green extraction. The crushed unripe grapes were extracted by the maceration system, the use of dry ice and membrane pneumatic press to prevent oxidative damage and increase the extraction yield.

In terms of the purity of extracted polyphenols, some studies elucidated that the use of macroporous resins is generally recommended because they possess suitable adsorption and desorption capabilities for polyphenol extraction [132]. The X-5 macroporous resin was selected for the purification of polyphenols extracted from unripe apple fruits. The phenolic content increased from $35.17 \%$ to $74.64 \%$, with a recovery yield of $89.35 \%$, which is a 2.12-fold increase. These authors selectively purified chlorogenic acid and phlorizin using X-5 and polyamide resins. The contents of chlorogenic acid and phlorizin were $15.20 \%$ and $97.52 \%$, with recovery yields of $89.16 \%$ and $64.95 \%$, respectively [133]. Sun et al. [134] performed dynamic adsorption and desorption by $\mathrm{X}-5$, polyamide resins, and a strippant of ethanol solution. Chlorogenic acid, epicatechin, hyperoside, and phlorizin were obtained from unripe apples with purities of $96.21 \%, 95.34 \%, 95.36 \%$, and 97.36\%, respectively.

\subsection{Methods to Extract Non-Phenolic Bioactive Compounds}

In the development of unripe fruits, few studies were performed on the extraction and purification of non-phenolic bioactive compounds. Due to the rich fiber content in unripe banana fruits, fiber powder from unripe banana was obtained by Rodriguez-Ambriz et al. [135] via a series of acidolyzed, liquefied, gelatinized, enzymatic hydrolyzed steps. In addition to fiber, the unripe banana is rich in starch. Khoozani et al. [136] studied the effect of different drying conditions, such as oven air-drying and freeze-drying, on the starch content, thermal properties and other physico-chemical parameters of unripe bananas flour. Banana flour dried using oven air at $50{ }^{\circ} \mathrm{C}$ and freeze-drying presented a higher resistant starch content. The first method showed the highest amylose content and degree of crystallinity and the lowest gelatinization temperature among the green banana flour samples $\left(4.69^{\circ} \mathrm{C}\right)$. These authors concluded that drying the unripe banana at 
$50{ }^{\circ} \mathrm{C}$ resulted in fewer negative effects on resistant starch content than those of the other drying temperatures studied and the flour produced exhibited similar physico-chemical characteristics compared to freeze-dried flour.

As mentioned above, the polysaccharides in unripe fruits have beneficial effects on the human body for example as antioxidant, so the extraction of polysaccharides is also worthy of further study (Figure 5). Dou et al. [137] used hot water extraction in a 70\% ethanol solution to remove polyphenols and the Sevage method to remove proteins and isolate crude polysaccharides from thinned unripe apples. Crude polysaccharides were separated using DEAE-52 cellulose column chromatography and eluted sequentially at a gradient of $0-0.5 \mathrm{moL} / \mathrm{L} \mathrm{NaCl}$ solution, with a flow rate of $1.0 \mathrm{~mL} / \mathrm{min}$. Samples were obtained using a DBS-100 collector. The total sugar mass fraction of crude polysaccharides after isolation and purification was $99.24 \%$ without impurities such as nucleic acids, proteins and polyphenols. Polysaccharides were also obtained from unripe apple fruits via hot water extraction at $88^{\circ} \mathrm{C}$ for $122 \mathrm{~min}$ [41]. After multiple elution using macroporous resin, the content of extracted polysaccharide reached $92 \%$, and they did not contain impurities such as proteins and polyphenols.

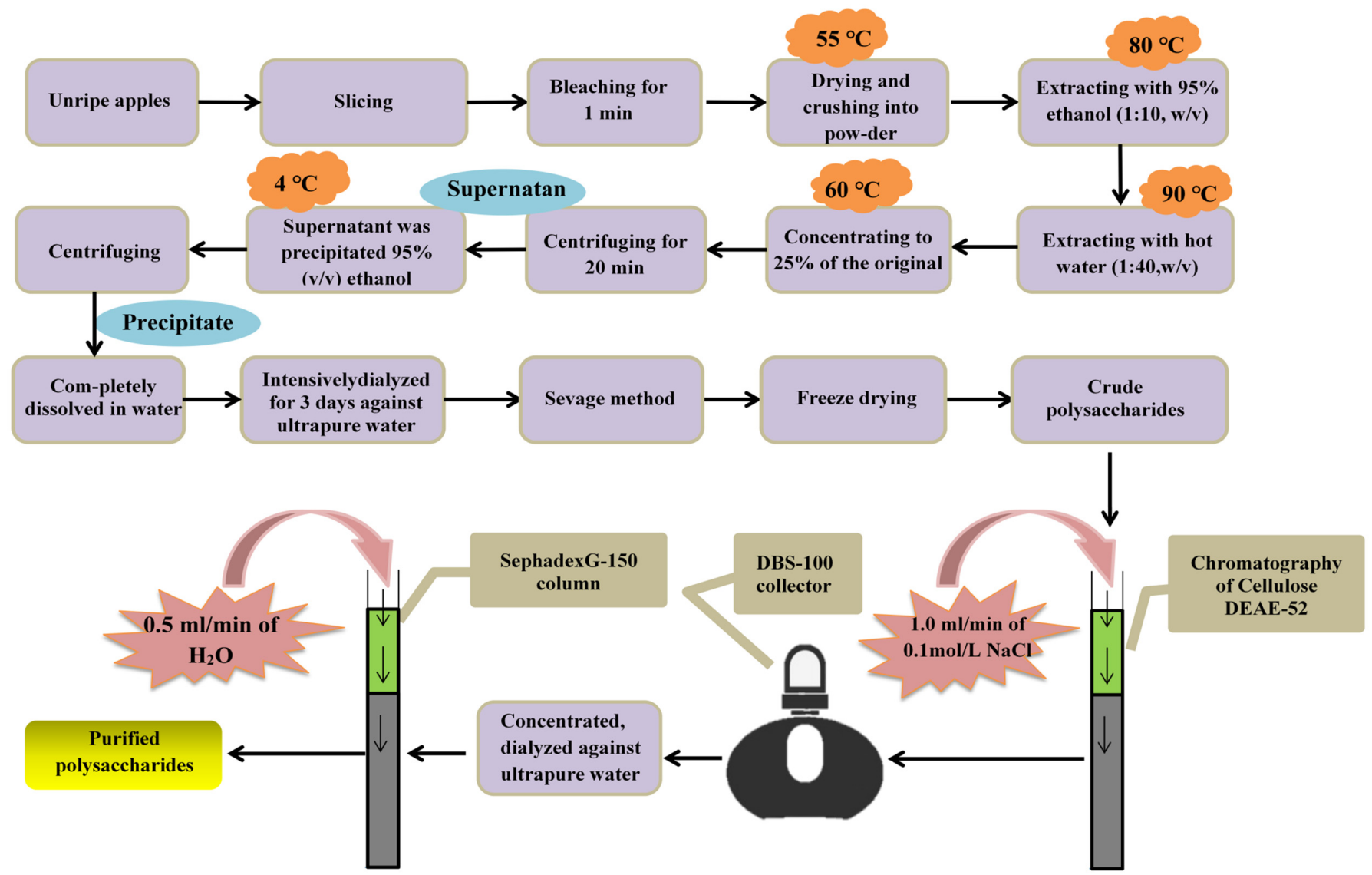

Figure 5. The entire process of the separation and purification of polysaccharides.

\section{Costs and Benefits}

As mentioned in the previous sections, thinned unripe fruits are generally discarded in the orchard, which generates much waste. Some researchers successively characterized the bioactive components of unripe fruits. These studies were performed to extract high-addedvalue components from unripe fruits for use in different fields such as in the cosmetic, pharmaceutical, food, and plastic industries or in energy production. The development of a fledgling industry of unripe fruit management could generate significant economic benefits in addition to the ecological benefits involved in the utilization of agricultural 
waste. Therefore, the discussion of costs and benefits is an inevitable topic in the process of unripe fruit management.

We will now take into account the report published by Sun et al. [134] that it is possible to roughly calculate the costs and benefits of the development of unripe apple fruit management. Sun et al. [133] used solvent extraction technology to extract polyphenols from $100 \mathrm{~g}$ fresh unripe apple fruit, and used resins to separate and purify crude polyphenols. The experimental consumables for the extraction of bioactive compounds from unripe fruits included hydrochloric acid, sodium hydroxide, ethanol, ethyl acetate, sodium sulfite, macroporous adsorption resin, chromatography columns, and peristaltic pumps. Unripe fruits are agricultural waste with extremely low commercial value and potential use, so we do not take a cost for them into account. The total cost was $\$ 111.198$, as shown in Table 5 .

Table 5. Costs produced from the extraction of monomeric phenols from thinned fruits.

\begin{tabular}{ccccc}
\hline & Consumable & Material Usage & Market Price (\$) & Total Price (\$) \\
\hline & $\mathrm{HCl}$ & $200 \mathrm{~mL}$ & $2.28 / 500 \mathrm{~mL}$ & 0.912 \\
& $\mathrm{NaOH}$ & $200 \mathrm{~g}$ & $1.57 / 500 \mathrm{~g}$ & 0.628 \\
Consumable & Alcohol & $2000 \mathrm{~mL}$ & $2.71 / 500 \mathrm{~mL}$ & 10.84 \\
test & Ethyl acetate & $800 \mathrm{~mL}$ & $1.99 / 500 \mathrm{~mL}$ & 3.184 \\
& Sodium sulfite & $300 \mathrm{~g}$ & $3.14 / 500 \mathrm{~g}$ & 1.884 \\
& Folin-Ciocalteu reagent & $10 \mathrm{~mL}$ & $10.57 / 50 \mathrm{~mL}$ & 2.11 \\
& Macroporous resin & $2000 \mathrm{~g}$ & $7.8 / 1000 \mathrm{~g}$ & 14.6 \\
& Column & 2 & $2.85 / \mathrm{set}$ & 5.7 \\
& Peristaltic pump & 1 & $71.34 / \mathrm{set}$ & 71.34 \\
\hline \multicolumn{5}{c}{ Total amount: \$111.198 } \\
\hline \multicolumn{4}{c}{}
\end{tabular}

In the course of the experiment, $0.534 \mathrm{~g}$ chlorogenic acid, $0.382 \mathrm{~g}$ epicatechin, $39.54 \mathrm{mg}$ hypericin, and $0.512 \mathrm{~g}$ phlorizin were obtained from $100 \mathrm{~g}$ fresh unripe apple fruit, and all with a purity higher than $95 \%$. We calculated the outputs according to the lowest price of the corresponding reagent published by the official website of the Sigma-Aldrich company. The total income produced from unripe fruit waste management was $\$ 1608.76$, as shown in Table 6. The economic benefits are close to 14-fold more than the costs, as shown in Figure 6 . However, if the development of the management of unripe fruits waste is extended to an industrial scale, the costs related to the use of water, electricity, man-hour labor costs, sewage treatment, raw material costs and storage should be considered. Nevertheless, the development of industrialization will multiply the number of bioactive compounds extracted and the number of monomeric phenols and many other by-products obtained, such as sour agents and polysaccharides. It is obvious that the benefits of unripe fruit development are very impressive.

Table 6. Incomes related to the obtaining of monomeric phenols from thinned fruits.

\begin{tabular}{ccccc}
\hline & Product & Yield/100 g & Market Price (\$) & Total Price (\$) \\
\hline \multirow{2}{*}{ High-added- } & Chlorogenic acid & $0.534 \mathrm{~g}$ & $129.66 / \mathrm{g}$ & 69.24 \\
value & Epicatechin & $0.382 \mathrm{~g}$ & $256.25 / \mathrm{g}$ & 97.89 \\
components & Hypericin & $39.54 \mathrm{mg}$ & $495.01 / 20 \mathrm{mg}$ & 978.64 \\
& Phlorizin & $0.512 \mathrm{~g}$ & $904.63 / \mathrm{g}$ & 463.17 \\
\hline \multicolumn{5}{c}{ Total amount: \$1608.76 } \\
\hline
\end{tabular}




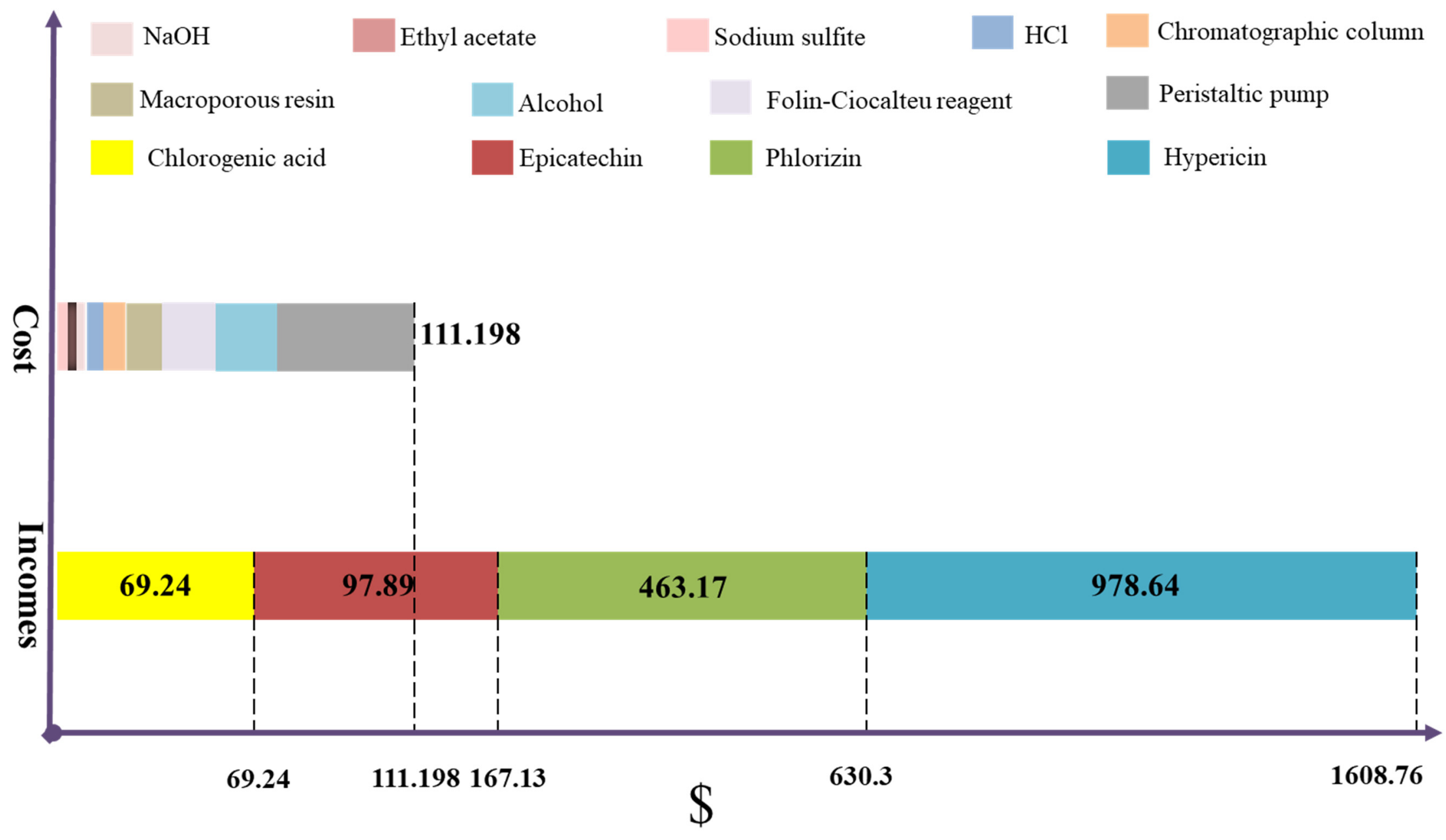

Figure 6. Costs and incomes produced from the extraction of monomeric phenols from thinned fruits. 
In addition, unripe fruits may also be used as food additives to replace the original materials to develop functional foods, such as unripe banana flour instead of wheat flour to make bread slices [138], and cakes that are rich in high dietary fiber [139]. Moreover, unripe banana powder may also be used as a snack instead of tapioca starch [140]. De Matos et al. [141] mentioned that unripe oranges could be used in salad dressings due to their low $\mathrm{pH}$ and antioxidant activity, and Öncül et al. [142] added unripe grape fruits to fruit juices and jams. There were no other extra costs added, and natural antioxidants from unripe fruits may increase the stunting of product to achieve the aim of increasing revenue. This use will promote the development of a circular economy that can reduce the environmental impacts of the non-management of thinned unripe fruits and improve the economic benefits of farmers.

\section{Outlook}

In summary, the thinned unripe fruits from horticultural crops are indeed a potential agricultural resource. Thinned fruit bioactive components, such as polyphenols, polysaccharides and organic acids, may be used in the food preservation, food additives, medicine, materials, cosmetics and other industries. However, the development of unripe fruits faces many challenges simultaneously.

Since unripe fruits are still growing, their bioactive components undergo different changes before thinning. The monitoring and recording of some physico-chemical parameters may be performed to establish a database of the bioactive components at different ripening stages of horticultural fruits. This measurement would help orchard coordination choose a suitable thinning date to maximize the content of bioactive compounds from thinned fruits without affecting the potential productivity of the orchard. Most of the collected thinned fruits are fallen fruits in soils, which presents serious problems in quality such as rotting, dehydration and the presence of insects. With the frequent use of inorganic fertilizers and pesticides, heavy metal and pesticide pollution of unripe fruits is inevitable. Therefore, collection, storage, preservation, and grading after thinning are equally important. Toxicity detection is also an essential link before unripe fruit are used as raw materials for semi-industrial and industrial purposes. How to reduce or eliminate potential harm from unripe fruit to health is one of the main challenges we must face in the future.

As mentioned above, the blend fermentation of unripe grapes and wine grapes can solve the disadvantage of "high sugar and low acid" caused by global warming. However, the addition of unripe fruit in wines may bring unpleasant green tastes to the wines. The removal of green tastes is a problem that needs to be solved in this process. In addition, different wine-making materials have different sugar and acid ratios, so the optimal amount of unripe fruit is often adjusted according to the quality of wine grapes.

Among the unripe fruits of many horticultural crops, unripe apples are the most investigated. Based on these studies, phenolic compounds are the most abundant bioactive components of unripe fruits. Although the polyphenol content in unripe fruits is higher than mature fruits, the proportion of total phenols extracted from unripe fruits is small. In addition, many resources are wasted in the extraction of monomeric phenols from unripe fruits. Therefore, future development and utilization of unripe fruits resources may resort to the "biorefinery" concept to fully extract and use high-value-added by-products from thinned fruits. Arevalo-Gallegos et al. [143] defines biorefinery as a sustainable method to convert biological raw materials (such as biomass) into energy in an economical and environmentally friendly manner. Thinned fruits as raw materials for biomass achieve faster material transfer due to their organoleptic wealth and internal morphological structure. Compared to wood or herbal biomass, acids, alkali catalysts, enzymes and microorganisms have higher activity in unripe fruits, which reduces the processing time. After the proper extraction of valuable bioactive compounds such as polyphenols, organic acids, polysaccharides, and starch from unripe fruits, heat may be used to quickly obtain biogas, bio-oil, and biochar via pyrolysis. These mixtures may be used to obtain sufficient energy $[20,24]$. 


\section{Conclusions}

This review summarized the comprehensive utilization of thinned unripe fruits from horticultural crops, especially apples, grapes, bananas, peaches, mangos, and kiwis. Thinned unripe fruits are often abandoned in orchards and cannot be optimally utilized. These unripe fruits are rich in several bioactive compounds, such as polyphenols, polysaccharides and organic acids. These compounds prevent oxidation, inhibit bacteria, reduce blood sugar, improve obesity, and possess emulsifying, thermoplastic, and stability properties. Increasingly, researchers have begun to extract high-value-added components from unripe fruits to generate a wide range of by-products for use in many industries such as medicine, food preservation, and polymer materials. Therefore, unripe fruits have great potential in the revalorization of agricultural wastes, which could improve economic benefits for farmers. Solving the environmental pressure of unripe fruits may also create greater economic benefits for agricultural workers.

Author Contributions: T.M., X.S. and Y.F. conceived and designed this critical revision. H.W., X.S. and M.W. studied the available information and wrote the manuscript. Q.G. modified the format and improved the language. All authors have read and agreed to the published version of the manuscript.

Institutional Review Board Statement: Not applicable.

Informed Consent Statement: Not applicable.

Data Availability Statement: Not applicable.

Acknowledgments: This study was supported by the National key research and development program of Ningxia (2021BEF02016), the National key research and development program of China (2019YFD1002502).

Conflicts of Interest: The authors declare that they do not have any conflict of interest.

\section{References}

1. Ouma, G. Fruit thinning with specific reference to citrus species: A review. Agric. Biol. J. N. Am. 2012, 3, 175-191. [CrossRef]

2. Frioni, T.; Zhuang, S.; Palliotti, A.; Sivilotti, P.; Falchi, R.; Sabbatini, P. Leaf removal and cluster thinning efficiencies are highly modulated by environmental conditions in cool climate viticulture. Am. J. Enol. Vitic. 2017, 68, 325-335. [CrossRef]

3. Byers, R.E. Flower and fruit thinning and vegetative: Fruiting balance. In Apples Botany Production E Uses; Department of Horticulture, Virginia Polytechnic Institute and State University: Winchester, VA, USA, 2003. [CrossRef]

4. Greene, D.; Costa, G. Fruit thinning in pome- and stone-fruit: State of the art. Acta Hortic. 2013, 93-102. [CrossRef]

5. Yeshitela, T.; Robbertse, P.J.; Fivas, J. Effects of fruit thinning on 'sensation' mango (Mangifera indica) trees with respect to fruit quantity, quality and tree phenology. Exp. Agric. 2004, 40, 433-444. [CrossRef]

6. Smith, M.S.; Centinari, M. Impacts of early leaf removal and cluster thinning on grüner veltliner production, fruit composition, and vine health. Am. J. Enol. Vitic. 2019, 70, 308-317. [CrossRef]

7. Gutierrez-Gamboa, G.; Wei, M.Y.; Moreno-Simunovic, Y.; Sun, X.Y.; Fang, Y.L. Potential opportunities of thinned clusters in viticulture: A mini review. J. Sci. Food Agric. 2020, 101, 4435-4443. [CrossRef] [PubMed]

8. Silvestre, J.P.; Roberto, S.R.; Colombo, R.C.; Goncalves, L.S.A.; Koyama, R.; Shahab, M.; Ahmed, S.; de Souza, R.T. Bunch sizing of 'BRS Nubia' table grape by inflorescence management, shoot tipping and berry thinning. Sci. Hortic. 2017, 225, 764-770. [CrossRef]

9. Seehuber, C.; Damerow, L.; Blanke, M. Regulation of source: Sink relationship, fruit set, fruit growth and fruit quality in european plum (Prunus domestica L.)-Using thinning for crop load management. Plant Growth Regul. 2011, 65, 335-341. [CrossRef]

10. Guardiola, J.L.; García-Luis, A. Increasing fruit size in citrus. Thinning and stimulation of fruit growth. Plant Growth Regul. 2000, 31, 121-132. [CrossRef]

11. Sakhidin, P.A.; Suparto, S.R. The influence of fruit thinning on fruit drop and quality of citrus. IOP Conf. Ser. Earth Environ. Sci. 2019, 250, 012096. [CrossRef]

12. Xi, X.; Zha, Q.; Jiang, A.; Tian, Y. Impact of cluster thinning on transcriptional regulation of anthocyanin biosynthesis-related genes in 'Summer Black' grapes. Plant Physiol. Biochem. 2016, 104, 180-187. [CrossRef]

13. Hehnen, D.; Hanrahan, I.; Lewis, K.; Mcferson, J.; Blanke, M. Mechanical flower thinning improves fruit quality of apples and promotes consistent bearing. Sci. Hortic. 2012, 134, 241-244. [CrossRef]

14. Costa, G.; Vizzotto, G. Fruit thinning of peach trees. Plant Growth Regul. 2000, 31, 113-119. [CrossRef]

15. Guo, C.T.; Li, X.; Bi, J.F.; Lv, J.; Wu, X.Y.; Lv, Y.; Xu, Y. Research achievements in bioactive components, functional properties and applications of thinned fruits. Food Sci. 2020, 41, 303-309. 
16. Chen, W.Q.; Guo, Y.R.; Zhang, J.; Zhang, X.R.; Meng, Y.H. Effect of different drying processes on the physicochemical and antioxidant properties of thinned unripe apple. Int. J. Food Eng. 2015, 11, 207-219. [CrossRef]

17. Yuan, R. Effects of temperature on fruit thinning with ethephon in 'Golden Delicious' apples. Sci. Hortic. 2007, 113, 8-12. [CrossRef]

18. Wertheim, S. Developments in the chemical thinning of apple and pear. Plant Growth Regul. 2000, 31, 85-100. [CrossRef]

19. Nuncio-Jáuregui, N.; Nowicka, P.; Munera-Picazo, S.; Hernández, F.; Carbonell-Barrachina, Á.A.; Wojdyło, A. Identification and quantification of major derivatives of ellagic acid and antioxidant properties of thinning and ripe Spanish pomegranates. J. Funct. Foods 2015, 12, 354-364. [CrossRef]

20. De La Torre, I.; Martin-Dominguez, V.; Acedos, M.G.; Esteban, J.; Santos, V.E.; Ladero, M. Utilisation/upgrading of orange peel waste from a biological biorefinery perspective. Appl. Microbiol. Biotechnol. 2019, 103, 5975-5991. [CrossRef] [PubMed]

21. Archimède, H.; González-García, E.; Despois, P.; Etienne, T.; Alexandre, G. Substitution of corn and soybean with green banana fruits and Gliricidia sepium forage in sheep fed hay-based diets: Effects on intake, digestion and growth. J. Anim. Physiol. Anim. Nutr. 2010, 94, 118-128. [CrossRef]

22. Azizi, M.; Seidavi, A.; Ragni, M.; Laudadio, V.; Tufarelli, V. Practical applications of agricultural wastes in poultry feeding in Mediterranean and Middle East regions. Part 1: Citrus, grape, pomegranate and apple wastes. Worlds Poult. Sci. J. 2018, 74, 489-498. [CrossRef]

23. Bampidis, V.; Robinson, P. Citrus by-products as ruminant feeds: A review. Anim. Feed. Sci. Technol. 2006, 128, 175-217. [CrossRef]

24. Alvarez, J.; Hooshdaran, B.; Cortazar, M.; Amutio, M.; Lopez, G.; Freire, F.B.; Haghshenasfard, M.; Hosseini, S.H.; Olazar, M. Valorization of citrus wastes by fast pyrolysis in a conical spouted bed reactor. Fuel 2018, 224, 111-120. [CrossRef]

25. Atchudan, R.; Edison, T.N.J.I.; Sethuraman, M.; Lee, Y.R. Efficient synthesis of highly fluorescent nitrogen-doped carbon dots for cell imaging using unripe fruit extract of Prunus mume. Appl. Surf. Sci. 2016, 384, 432-441. [CrossRef]

26. Ritthiruangdej, P.; Parnbankled, S.; Donchedee, S.; Wongsagonsup, R. Physical, chemical, textural and sensory properties of dried wheat noodles supplemented with unripe banana flour. Kasetsart J. Soc. Sci. 2011, 45, 500-509.

27. Shin, T.Y.; Shin, H.Y.; Kim, S.H.; Kim, D.K.; Park, J.S. Rubus coreanus unripe fruits inhibits immediate-type allergic reaction and inflammatory cytokine secretion. Nat. Prod. Sci. 2006, 12, 144-149.

28. Thomas, K.D.; Bola, A. Antisickling agent in an extract of unripe pawpaw fruit (Carica papaya). Trans. R. Soc. Trop. Med. Hyg. 1987, 3, 10. [CrossRef]

29. Hwang, H.; Kim, Y.-J.; Shin, Y. Assessment of Physicochemical Quality, Antioxidant Content and Activity, and Inhibition of Cholinesterase between Unripe and Ripe Blueberry Fruit. Foods 2020, 9, 690. [CrossRef]

30. Hiraga, Y.; Ara, T.; Sato, N.; Akimoto, N.; Sugiyama, K.; Suzuki, H.; Kera, K. Metabolic analysis of unripe papaya (Carica papaya L.) to promote its utilization as a functional food. Biosci. Biotechnol. Biochem. 2021, 85, 1194-1204. [CrossRef]

31. Nasser, M.; Cheikh-Ali, H.; Hijazi, A.; Merah, O.; Al-Rekaby, A.E.-A.N.; Awada, R. Phytochemical Profile, Antioxidant and Antitumor Activities of Green Grape Juice. Processes 2020, 8, 507. [CrossRef]

32. Hou, Y.; Gong, T.; Zhang, J.; Yang, X.; Guo, Y. Structural characterization and emulsifying properties of thinned-young apples polysaccharides. Biochem. Biophys. Res. Commun. 2019, 516, 1175-1182. [CrossRef]

33. Li, W. Anti-Inflammatory Mechanism and Effect on Ulcerative Colitis of Polysaccharides from Hericium erinaceus Mycelium; Jiangnan University: Wuxi, China, 2017.

34. Honisch, C.; Osto, A.; De Matos, A.D.; Vincenzi, S.; Ruzza, P. Isolation of a tyrosinase inhibitor from unripe grapes juice: A spectrophotometric study. Food Chem. 2020, 305, 125506. [CrossRef]

35. Jančářová, I.; Jančář, L.; Náplavová, A.; Kubáň, V. Changes of organic acids and phenolic compounds contents in grapevine berries during their ripening. Open Chem. 2013, 11, 1575-1582. [CrossRef]

36. Zheng, H.-Z.; Kim, Y.-I.; Chung, S.-K. A profile of physicochemical and antioxidant changes during fruit growth for the utilisation of unripe apples. Food Chem. 2012, 131, 106-110. [CrossRef]

37. Jiao, Y.; Chen, D.; Fan, M.; Quek, S.Y. UPLC-QqQ-MS/MS-based phenolic quantification and antioxidant activity assessment for thinned young kiwifruits. Food Chem. 2019, 281, 97-105. [CrossRef] [PubMed]

38. Labbé, M.; Ulloa, P.A.; López, F.; Sáenz, C.; Peña, Á.; Salazar, F.N. Characterization of chemical compositions and bioactive compounds in juices from pomegranates ('Wonderful', 'Chaca' and 'Codpa') at different maturity stages. Chil. J. Agric. Res. 2016, 76, 479-486. [CrossRef]

39. Hwang, H.; Kim, Y.-J.; Shin, Y. Influence of ripening stage and cultivar on physicochemical properties, sugar and organic acid profiles, and antioxidant compositions of strawberries. Food Sci. Biotechnol. 2019, 28, 1659-1667. [CrossRef] [PubMed]

40. Omoba, O.S.; Obafaye, R.O.; Salawu, S.O.; Boligon, A.A.; Athayde, M.L. HPLC-DAD Phenolic Characterization and Antioxidant Activities of Ripe and Unripe Sweet Orange Peels. Antioxidants 2015, 4, 498-512. [CrossRef]

41. Bagheri, H.; Esmaiili, M. Ultrasound-Assisted Extraction of Phenolic Compounds from Unripe Grape (Qora). Erwerbs-Obstbau 2017, 59, 221-226. [CrossRef]

42. Redondo, D.; Arias, E.; Oria, R.; Venturini, M.E. Thinned stone fruits are a source of polyphenols and antioxidant compounds. J. Sci. Food Agric. 2016, 97, 902-910. [CrossRef]

43. Salces, R.M.A.; Herrero, C.; Barranco, A.; Berrueta, L.A.; Gallo, B.; Vicente, F. Classification of apple fruits according to their maturity state by the pattern recognition analysis of their polyphenolic compositions. Food Chem. 2005, 93, 113-123. [CrossRef] 
44. Sun, L.; Chen, W.; Meng, Y.; Yang, X.; Yuan, L.; Guo, Y. Interactions between polyphenols in thinned young apples and porcine pancreatic $\alpha$-amylase: Inhibition, detailed kinetics and fluorescence quenching. Food Chem. 2016, 208, 51-60. [CrossRef] [PubMed]

45. Nakashima, S.; Oda, C.; Masuda, S.; Tagashira, M.; Kanda, T. Isolation and structure elucidation of tetrameric procyanidins from unripe apples (Malus pumila cv. Fuji) by NMR spectroscopy. Phytochemistry 2012, 83, 144-152. [CrossRef]

46. Sun, L.; Tao, S.; Zhang, S. Characterization and Quantification of Polyphenols and Triterpenoids in Thinned Young Fruits of Ten Pear Varieties by UPLC-Q TRAP-MS/MS. Molecules 2019, 24, 159. [CrossRef] [PubMed]

47. Scordino, M.; Sabatino, L.; Belligno, A.; Gagliano, G. Characterization of Polyphenolic Compounds in Unripe Chinotto (Citrus myrtifolia) Fruit by HPLC/PDA/ESI/MS-MS. Nat. Prod. Commun. 2011, 6, 1857-1862. [CrossRef] [PubMed]

48. Yang, J.; Cui, J.; Wu, Y.; Han, H.; Chen, J.; Yao, J.; Liu, Y. Comparisons of the active components in four unripe raspberry extracts and their activites. Food Sci. Technol. 2019, 39, 632-639. [CrossRef]

49. De Matos, A.D.; Curioni, A.; Bakalinsky, A.T.; Marangon, M.; Pasini, G.; Vincenzi, S. Chemical and sensory analysis of verjuice: An acidic food ingredient obtained from unripe grape berries. Innov. Food Sci. Emerg. Technol. 2017, 44, 9-14. [CrossRef]

50. Kim, H.-R.; Kim, I.-D.; Dhungana, S.K.; Kim, M.-O.; Shin, D.-H.; Waqas, M. Comparative assessment of physicochemical properties of unripe peach (Prunus persica) and Japanese apricot (Prunus mume). Asian Pac. J. Trop. Biomed. 2014, 4, 97-103. [CrossRef]

51. Colin-Henrion, M.; Mehinagic, E.; Renard, C.M.; Richomme, P.; Jourjon, F. From apple to applesauce: Processing effects on dietary fibres and cell wall polysaccharides. Food Chem. 2009, 117, 254-260. [CrossRef]

52. Zhang, T.; Tian, Y.; Jiang, B.; Miao, M.; Mu, W. Purification, preliminary structural characterization and in vitro antioxidant activity of polysaccharides from Acanthus ilicifolius. LWT 2014, 56, 9-14. [CrossRef]

53. MacDougall, A.J.; Needs, P.W.; Rigby, N.M.; Ring, S.G. Calcium gelation of pectic polysaccharides isolated from unripe tomato fruit. Carbohydr. Res. 1996, 293, 235-249. [CrossRef]

54. Dou, J.; Meng, Y.; Liu, L.; Li, J.; Ren, D.; Guo, Y. Purification, characterization and antioxidant activities of polysaccharides from thinned-young apple. Int. J. Biol. Macromol. 2015, 72, 31-40. [CrossRef]

55. Marenda, F.R.B.; Colodel, C.; Canteri, M.H.G.; Müller, C.M.D.O.; Amante, E.R.; Petkowicz, C.; Amboni, R.D.D.M.C. Investigation of cell wall polysaccharides from flour made with waste peel from unripe banana (Musa sapientum) biomass. J. Sci. Food Agric. 2019, 99, 4363-4372. [CrossRef] [PubMed]

56. Bi, Y. Effect of Ripening on Physicochemical Properties, Starch Digestibility and Starch Fine Structure of Banana Flour; Jiangnan University: Wuxi, China, 2018.

57. Espinosa-Solis, V.; Jane, J.-L.; Bello-Perez, L.A. Physicochemical Characteristics of Starches from Unripe Fruits of Mango and Banana. Starch-Stärke 2009, 61, 291-299. [CrossRef]

58. Moongngarm, A.; Tiboonbun, W.; Sanpong, M.; Sriwong, P.; Phiewtong, L.; Prakitrum, R.; Huychan, N. Resistant starch and bioactive contents of unripe banana flour as influenced by harvesting periods and its application. Am. J. Agric. Biol. Sci. 2014, 9 , 457-465. [CrossRef]

59. Menezes, E.W.; Tadini, C.C.; Tribess, T.B.; Zuleta, A.; Binaghi, J.; Pak, N.; Vera, G.; Dan, M.C.T.; Bertolini, A.C.; Cordenunsi, B.R.; et al. Chemical Composition and Nutritional Value of Unripe Banana Flour (Musa acuminata, var. Nanicão). Plant Foods Hum. Nutr. 2011, 66, 231-237. [CrossRef]

60. Patiño-Rodríguez, O.; Agama-Acevedo, E.; Ramos-Lopez, G.; Bello-Pérez, L.A. Unripe mango kernel starch: Partial characterization. Food Hydrocoll. 2020, 101, 105512. [CrossRef]

61. Li, D.; Zhu, F. Starch structure in developing kiwifruit. Int. J. Biol. Macromol. 2018, 120, 1306-1314. [CrossRef]

62. Kris-Etherton, P.M.; Hecker, K.D.; Bonanome, A.; Coval, S.M.; Binkoski, A.E.; Hilpert, K.F.; Griel, A.E.; Etherton, T.D. Bioactive compounds in foods: Their role in the prevention of cardiovascular disease and cancer. Am. J. Med. 2002, 113, 71-88. [CrossRef]

63. Kovacevic, D.B.; Brdar, D.; Fabecic, P.; Barba, F.J.; Lorenzo, J.M.; Putnik, P. Strategies to achieve a healthy and balanced diet: Fruits and vegetables as a natural source of bioactive compounds. In Agri-Food Industry Strategies for Healthy Diets and Sustainability; Academic Press: Cambridge, MA, USA, 2020; pp. 51-88. [CrossRef]

64. Liu, R.H. Health benefits of fruit and vegetables are from additive and synergistic combinations of phytochemicals. Am. J. Clin. Nutr. 2003, 78, 517S-520S. [CrossRef]

65. Olsson, M.E.; Gustavsson, K.E.; Andersson, S.; Nilsson, A.; Duan, R.D. Inhibition of Cancer Cell Proliferation in Vitro by Fruit and Berry Extracts and Correlations with Antioxidant Levels. J. Agric. Food Chem. 2004, 52, 7264-7271. [CrossRef]

66. Sun, J.; Chu, Y.-F.; Wu, X.; Liu, R.H. Antioxidant and Antiproliferative Activities of Common Fruits. J. Agric. Food Chem. 2002, 50, 7449-7454. [CrossRef]

67. Chen, Y.; Pan, H.; Hao, S.; Pan, D.; Wang, G.; Yu, W. Evaluation of phenolic composition and antioxidant properties of different varieties of Chinese citrus. Food Chem. 2021, 364, 130413. [CrossRef]

68. Moura, H.F.S.; Dias, F.D.S.; e Souza, L.B.S.; de Magalhães, B.E.A.; Tannus, C.D.A.; de Carvalho, W.C.; Brandão, G.C.; dos Santos, W.N.L.; Korn, M.G.A.; dos Santos, D.C.M.B.; et al. Evaluation of multielement/proximate composition and bioactive phenolics contents of unconventional edible plants from Brazil using multivariate analysis techniques. Food Chem. 2021, $363,129995$. [CrossRef]

69. Villarroel-Vicente, C.; Gutiérrez-Palomo, S.; Ferri, J.; Cortes, D.; Cabedo, N. Natural products and analogs as preventive agents for metabolic syndrome via peroxisome proliferator-activated receptors: An overview. Eur. J. Med. Chem. 2021, $221,113535$. [CrossRef] [PubMed] 
70. Abe, D.; Saito, T.; Kubo, Y.; Nakamura, Y.; Sekiya, K. A fraction of unripe kiwi fruit extract regulates adipocyte differentiation and function in 3T3-L1 cells. BioFactors 2010, 36, 52-59. [CrossRef]

71. Bhinge, S.D.; Bhutkar, M.; Randive, D.; Wadkar, G.; Jadhav, N.; Jadhav, A.; Ingalkar, R. Comparative in vitro hypoglycemic studies of unripe, ripe and overripe fruit extract of Musa paradisiaca (Indian banana). Br. Food J. 2019, 121, 1236-1247. [CrossRef]

72. Makarova, E.; Górnaś, P.; Konrade, I.; Tirzite, D.; Cirule, H.; Gulbe, A.; Pugajeva, I.; Seglina, D.; Dambrova, M. Acute antihyperglycaemic effects of an unripe apple preparation containing phlorizin in healthy volunteers: A preliminary study. J. Sci. Food Agric. 2015, 95, 560-568. [CrossRef] [PubMed]

73. Zibaeenezhad, M.; Mohammadi, E.; Beigi, M.A.B.; Mirzamohammadi, F.; Salehi, O. The Effects of Unripe Grape Juice on Lipid Profile Improvement. Cholesterol 2012, 2012, 890262. [CrossRef]

74. Karabiyikli, Ş.; Öncül, N. Inhibitory Effect of Unripe Grape Products on Foodborne Pathogens. J. Food Process. Preserv. 2016, 40, 1459-1465. [CrossRef]

75. Zhang, J.; Chen, W.; Li, S.; Xue, Z.; Zheng, W.; Guo, Y. Antibacterial activity and preservative properties of thinned young apples extracts for fish flesh. J. Food Process. Preserv. 2017, 42, e13435. [CrossRef]

76. Yonezawa, T.; Momota, R.; Iwano, H.; Zhao, S.; Hakozaki, T.; Soh, C.; Ba, S.S.; Toyama, K.; Oohashi, T. Unripe peach (Prunus persica) extract ameliorates damage from UV irradiation and improved collagen XVIII expression in 3D skin model. J. Cosmet. Dermatol. 2018, 18, 1507-1515. [CrossRef] [PubMed]

77. Park, E.K.; Ahn, S.R.; Kim, D.-H.; Lee, E.-W.; Kwon, H.J.; Kim, B.W.; Kim, T.H. Effects of unripe apple polyphenols on the expression of matrix metalloproteinase-1 and type-1 procollagen in ultraviolet irradiated human skin fibroblasts. J. Korean Soc. Appl. Biol. Chem. 2014, 57, 449-455. [CrossRef]

78. Khoddami, A.; Wilkes, M.A.; Roberts, T.H. Techniques for Analysis of Plant Phenolic Compounds. Molecules 2013, 18, 2328-2375. [CrossRef] [PubMed]

79. Cao, Q.; Teng, J.; Wei, B.; Huang, L.; Xia, N. Phenolic compounds, bioactivity, and bioaccessibility of ethanol extracts from passion fruit peel based on simulated gastrointestinal digestion. Food Chem. 2021, 356, 129682. [CrossRef]

80. Mohanlal, S.; Parvathy, R.; Shalini, V.; Mohanan, R.; Helen, A.; Jayalekshmy, A. Chemical indices, antioxidant activity and anti-inflammatory effect of extracts of the medicinal rice "njavara" and staple varieties: A comparative study. J. Food Biochem. 2012, 37, 369-380. [CrossRef]

81. Roleira, F.M.; da Silva, E.T.; Varela, C.; Costa, S.; Silva, T.; Garrido, J.; Borges, F. Plant derived and dietary phenolic antioxidants: Anticancer properties. Food Chem. 2015, 183, 235-258. [CrossRef]

82. Dai, J.; Mumper, R.J. Plant Phenolics: Extraction, Analysis and Their Antioxidant and Anticancer Properties. Molecules 2010, 15, 7313-7352. [CrossRef]

83. Jiang, H.; Zhang, W.; Li, X.; Xu, Y.; Cao, J.; Jiang, W. The anti-obesogenic effects of dietary berry fruits: A review. Food Res. Int. 2021, 147, 110539. [CrossRef]

84. Castrejón, A.D.R.; Eichholz, I.; Rohn, S.; Kroh, L.W.; Huyskens-Keil, S. Phenolic profile and antioxidant activity of highbush blueberry (Vaccinium corymbosum L.) during fruit maturation and ripening. Food Chem. 2008, 109, 564-572. [CrossRef]

85. Jiang, H.; Ji, B.; Liang, J.; Zhou, F.; Yang, Z.; Zhang, G. Changes of contents and antioxidant activities of polyphenols during fruit development of four apple cultivars. Eur. Food Res. Technol. 2006, 223, 743-748. [CrossRef]

86. Lu, Y.; Yeap, F.L. Antioxidant and radical scavenging activities of polyphenols from apple pomace. Food Chem. 2000, 68, 81-85. [CrossRef]

87. Lamperi, L.; Chiuminatto, U.; Cincinelli, A.; Galvan, P.; Giordani, E.; Lepri, L.; Del Bubba, M. Polyphenol Levels and Free Radical Scavenging Activities of Four Apple Cultivars from Integrated and Organic Farming in Different Italian Areas. J. Agric. Food Chem. 2008, 56, 6536-6546. [CrossRef]

88. Yue, T.; Shao, D.; Yuan, Y.; Wang, Z.; Qiang, C. Ultrasound-assisted extraction, HPLC analysis, and antioxidant activity of polyphenols from unripe apple. J. Sep. Sci. 2012, 35, 2138-2145. [CrossRef]

89. Tinello, F.; Lante, A. Evaluation of antibrowning and antioxidant activities in unripe grapes recovered during bunch thinning. Aust. J. Grape Wine Res. 2017, 23, 33-41. [CrossRef]

90. Choi, S.-Y.; Kim, S.-S.; Lee, Y.-M.; Lee, B.-H.; Han, C.-K. Phenolic Compounds Content and Tyrosinase Inhibitory Effect of Unripe Apple Extracts. J. Appl. Biol. Chem. 2010, 53, 87-90. [CrossRef]

91. Billaud, C.; Lecornu, D.; Nicolas, J. Substrates and Carboxylic Acid Inhibitors of a Partially Purified Polyphenol Oxidase from Gum Arabic. J. Agric. Food Chem. 1996, 44, 1668-1675. [CrossRef]

92. Kim, D.-M.; Kim, K.-H.; Kim, Y.-S.; Koh, J.-H.; Lee, K.-H.; Yook, H.-S. A Study on the Development of Cosmetic Materials Using Unripe Peaches Seed Extracts. J. Korean Soc. Food Sci. Nutr. 2012, 41, 110-115. [CrossRef]

93. Sun, L.; Sun, J.; Thavaraj, P.; Yang, X.; Guo, Y. Effects of thinned young apple polyphenols on the quality of grass carp (Ctenopharyngodon idellus) surimi during cold storage. Food Chem. 2017, 224, 372-381. [CrossRef]

94. Sun, L.; Sun, J.; Chen, L.; Niu, P.; Yang, X.; Guo, Y. Preparation and characterization of chitosan film incorporated with thinned young apple polyphenols as an active packaging material. Carbohydr. Polym. 2017, 163, 81-91. [CrossRef] [PubMed]

95. Nisar, T.; Wang, Z.-C.; Alim, A.; Iqbal, M.; Yang, X.; Sun, L.; Guo, Y. Citrus pectin films enriched with thinned young apple polyphenols for potential use as bio-based active packaging. CyTA J. Food 2019, 17, 695-705. [CrossRef]

96. Franco, P.B.; De Almeida, L.A.; Marques, R.F.C.; Brucha, G.; Campos, M.G.N. Evaluation of Antibacterial Activity of Chitosan Membranes Associated to Unripe Banana Peel. Mater. Sci. Forum 2016, 869, 859-863. [CrossRef] 
97. Simonetti, G.; D’Auria, F.D.; Mulinacci, N.; Milella, R.A.; Antonacci, D.; Innocenti, M.; Pasqua, G. Phenolic content and in vitro antifungal activity of unripe grape extracts from agro-industrial wastes. Nat. Prod. Res. 2017, 33, 803-807. [CrossRef]

98. Granato, D.; Barba, F.J.; Bursać Kovačević, D.; Lorenzo, J.M.; Cruz, A.G.; Putnik, P. Functional Foods: Product Development, Technological Trends, Efficacy Testing, and Safety. Annu. Rev. Food Sci. Technol. 2020, 11, 93-118. [CrossRef]

99. Öncül, N.; Karabiyikli, S. Persistence and survival of some food borne pathogens in neutralized unripe grape products. Ukranian Food J. 2016, 5, 96-108.

100. Turkmen, F.U.; Takci, H.A.M.; Sekeroglu, N. Total Phenolic and Flavonoid Contents, Antioxidant and Antimicrobial Activities of Traditional Unripe Grape Products. Indian J. Pharm. Educ. Res. 2017, 51, s489-s493. [CrossRef]

101. Bucalossi, G.; Fia, G.; Dinnella, C.; De Toffoli, A.; Canuti, V.; Zanoni, B.; Servili, M.; Pagliarini, E.; Toschi, T.G.; Monteleone, E. Functional and sensory properties of phenolic compounds from unripe grapes in vegetable food prototypes. Food Chem. 2020, 315, 126291. [CrossRef]

102. Dan, M.C.T.; Cardenette, G.H.L.; Sardá, F.A.H.; Giuntini, E.B.; Bello-Pérez, L.A.; Carpinelli, Â.R.; Lajolo, F.M.; Menezes, E.W. Colonic Fermentation of Unavailable Carbohydrates from Unripe Banana and Its Influence over Glycemic Control. Plant Foods Hum. Nutr. 2015, 70, 297-303. [CrossRef]

103. Sardá, F.A.H.; Giuntini, E.B.; Gomez, M.L.P.; Lui, M.C.Y.; Negrini, J.A.; Tadini, C.; Lajolo, F.M.; Menezes, E.W. Impact of resistant starch from unripe banana flour on hunger, satiety, and glucose homeostasis in healthy volunteers. J. Funct. Foods 2016, 24, 63-74. [CrossRef]

104. Rosado, C.P.; Rosa, V.H.C.; Martins, B.C.; Soares, A.C.; Santos, I.B.; Monteiro, E.B.; Moura-Nunes, N.; da Costa, C.A.; Mulder, A.D.R.P.; Daleprane, J.B. Resistant starch from green banana (Musa sp.) attenuates non-alcoholic fat liver accumulation and increases short-chain fatty acids production in high-fat diet-induced obesity in mice. Int. J. Biol. Macromol. 2020, 145, 1066-1072. [CrossRef]

105. Chen, L.; Yang, X.; Liu, R.; Liu, L.; Zhao, D.; Liu, J.; Guo, Y.; Long, J. Thinned young apple polysaccharide improves hepatic metabolic disorder in high-fat diet-induced obese mice by activating mitochondrial respiratory functions. J. Funct. Foods 2017, 33, 396-407. [CrossRef]

106. Castaño, M.M.; Lopera-Idarraga, J.; Pazmiño-Arteaga, J.; Gallardo-Cabrera, C. Evaluation of the behaviour of unripe banana flour with non-conventional flours in the production of gluten-free bread. Food Sci. Technol. Int. 2019, 26, 160-172. [CrossRef]

107. Patiño-Rodríguez, O.; Agama-Acevedo, E.; Pacheco-Vargas, G.; Alvarez-Ramirez, J.; Bello-Pérez, L.A. Physicochemical, microstructural and digestibility analysis of gluten-free spaghetti of whole unripe plantain flour. Food Chem. 2019, $298,125085$. [CrossRef] [PubMed]

108. Aguirre, M.A.H.; Islas-Hernández, J.J.; Sánchez-Pardo, M.E.; Rodríguez-Ambriz, S.L.; Osorio-Díaz, P. Response surface methodology for optimization of gluten-free bread made with unripe banana flour. J. Food Meas. Charact. 2019, 13, 1652-1660. [CrossRef]

109. Alves, L.A.A.D.S.; Lorenzo, J.M.; Gonçalves, C.A.A.; dos Santos, B.A.; Heck, R.T.; Cichoski, A.J.; Campagnol, P.C.B. Production of healthier bologna type sausages using pork skin and green banana flour as a fat replacers. Meat Sci. 2016, 121, 73-78. [CrossRef] [PubMed]

110. De Souza, N.C.O.; Oliveira, L.D.L.D.; de Alencar, E.R.; Moreira, G.P.; Leandro, E.D.S.; Ginani, V.C.; Zandonadi, R.P. Textural, physical and sensory impacts of the use of green banana puree to replace fat in reduced sugar pound cakes. LWT 2018, 89, 617-623. [CrossRef]

111. Waghmare, A.G.; Arya, S.S. Utilization of unripe banana peel waste as feedstock for ethanol production. Bioethanol 2016, 2, 146-156. [CrossRef]

112. Kontoudakis, N.; Esteruelas, M.; Fort, F.; Canals, J.-M.; Zamora, F. Use of unripe grapes harvested during cluster thinning as a method for reducing alcohol content and $\mathrm{pH}$ of wine. Aust. J. Grape Wine Res. 2011, 17, 230-238. [CrossRef]

113. Piccardo, D.; Favre, G.; Pascual, O.; Canals, J.M.; Zamora, F.; González-Neves, G. Influence of the use of unripe grapes to reduce ethanol content and $\mathrm{pH}$ on the color, polyphenol and polysaccharide composition of conventional and hot macerated Pinot Noir and Tannat wines. Eur. Food Res. Technol. 2019, 245, 1321-1335. [CrossRef]

114. Martínez de Toda, F.; Balda, P. Decreasing the alcohol level in quality red wines by the "double harvest" technique. In Proceedings of the 17th International Symposium Giesco, Asti, Italia, 29 August-2 September 2011.

115. Fia, G.; Bucalossi, G.; Zanoni, B. Characterisation of Extracts Obtained from Unripe Grapes and Evaluation of Their Potential Protective Effects against Oxidation of Wine Colour in Comparison with Different Oenological Products. Foods 2021, 10, 1499. [CrossRef]

116. Junior, W.J.F.L.; Nadai, C.; Crepalde, L.T.; de Oliveira, V.; de Matos, A.D.; Giacomini, A.; Corich, V. Potential use of Starmerella bacillaris as fermentation starter for the production of low-alcohol beverages obtained from unripe grapes. Int. J. Food Microbiol. 2019, 303, 1-8. [CrossRef] [PubMed]

117. Cascales, A.I.; Costell, E.; Romojaro, F. Effects of the Degree of Maturity on the Chemical Composition, Physical Characteristics and Sensory Attributes of Peach (Prunus persica) cv. Caterin. Food Sci. Technol. Int. 2005, 11, 345-352. [CrossRef]

118. Atchudan, R.; Edison, T.N.J.I.; Lee, Y.R. Nitrogen-doped carbon dots originating from unripe peach for fluorescent bioimaging and electrocatalytic oxygen reduction reaction. J. Colloid Interface Sci. 2016, 482, 8-18. [CrossRef] [PubMed]

119. Martínez, E.S.M.; Méndez, M.A.A.; Sanchez-Solis, A.; Vieyra, H. Thermoplastic biodegradable material elaborated from unripe banana flour reinforced with metallocene catalyzed polyethylene. Polym. Eng. Sci. 2015, 55, 866-876. [CrossRef] 
120. Junior, C.P.A.; Coaquira, C.A.C.; Mattos, A.; Filho, M.D.S.M.D.S.; Feitosa, J.P.D.A.; De Morais, J.P.S.; Rosa, M.D.F. Binderless Fiberboards Made from Unripe Coconut Husks. Waste Biomass Valoriz. 2017, 9, 2245-2254. [CrossRef]

121. Kammerer, J.; Schweizer, C.; Carle, R.; Kammerer, D.R. Recovery and fractionation of major apple and grape polyphenols from model solutions and crude plant extracts using ion exchange and adsorbent resins. Int. J. Food Sci. Technol. 2011, 46, 1755-1767. [CrossRef]

122. Aliakbarian, B.; Fathi, A.; Perego, P.; Dehghani, F. Extraction of antioxidants from winery wastes using subcritical water. J. Supercrit. Fluids 2012, 65, 18-24. [CrossRef]

123. Pingret, D.; Fabiano-Tixier, A.-S.; Le Bourvellec, C.; Renard, C.M.G.C.; Chemat, F. Lab and pilot-scale ultrasound-assisted water extraction of polyphenols from apple pomace. J. Food Eng. 2012, 111, 73-81. [CrossRef]

124. Zheng, H.-Z.; Hwang, I.-W.; Kim, S.-K.; Lee, S.-H.; Chung, S.-K. Optimization of Carbohydrate-hydrolyzing Enzyme Aided Polyphenol Extraction from Unripe Apples. J. Korean Soc. Appl. Biol. Chem. 2010, 53, 342-350. [CrossRef]

125. Landbo, A.-K.; Meyer, A.S. Enzyme-Assisted Extraction of Antioxidative Phenols from Black Currant Juice Press Residues (Ribes nigrum). J. Agric. Food Chem. 2001, 49, 3169-3177. [CrossRef]

126. Meyer, A.S.; Jepsen, A.S.M.; Sørensen, N.S. Enzymatic Release of Antioxidants for Human Low-Density Lipoprotein from Grape Pomace. J. Agric. Food Chem. 1998, 46, 2439-2446. [CrossRef]

127. Sørensen, H.R.; Pedersen, S.; Viksø-Nielsen, A.; Meyer, A.S. Efficiencies of designed enzyme combinations in releasing arabinose and xylose from wheat arabinoxylan in an industrial ethanol fermentation residue. Enzym. Microb. Technol. 2005, 36, 773-784. [CrossRef]

128. Zheng, H.-Z.; Hwang, I.-W.; Chung, S.-K. Enhancing polyphenol extraction from unripe apples by carbohydrate-hydrolyzing enzymes. J. Zhejiang Univ. Sci. B 2009, 10, 912-919. [CrossRef] [PubMed]

129. Shojaee-Aliabadi, S.; Hosseini, S.M.; Tiwari, B.; Hashemi, M.; Fadavi, G.; Khaksar, R. Polyphenols content and antioxidant activity of Ghure (unripe grape) marc extract: Influence of extraction time, temperature and solvent type. Int. J. Food Sci. Technol. 2013, 48, 412-418. [CrossRef]

130. Wang, H.; Liu, T.; Song, L.; Huang, D. Profiles and $\alpha$-Amylase Inhibition Activity of Proanthocyanidins in Unripe Manilkara zapota (Chiku). J. Agric. Food Chem. 2012, 60, 3098-3104. [CrossRef]

131. Fia, G.; Bucalossi, G.; Gori, C.; Borghini, F.; Zanoni, B. Recovery of Bioactive Compounds from Unripe Red Grapes (cv. Sangiovese) through a Green Extraction. Foods 2020, 9, 566. [CrossRef]

132. Kammerer, J.; Kammerer, D.R.; Jensen, U.; Carle, R. Interaction of apple polyphenols in a multi-compound system upon adsorption onto a food-grade resin. J. Food Eng. 2010, 96, 544-554. [CrossRef]

133. Sun, L.; Guo, Y.; Fu, C.; Li, J.; Li, Z. Simultaneous separation and purification of total polyphenols, chlorogenic acid and phlorizin from thinned young apples. Food Chem. 2013, 136, 1022-1029. [CrossRef]

134. Sun, L.; Liu, D.; Sun, J.; Yang, X.; Fu, M.; Guo, Y. Simultaneous separation and purification of chlorogenic acid, epicatechin, hyperoside and phlorizin from thinned young Qinguan apples by successive use of polyethylene and polyamide resins. Food Chem. 2017, 230, 362-371. [CrossRef] [PubMed]

135. Rodríguez-Ambriz, S.; Islas-Hernández, J.; Agama-Acevedo, E.; Tovar, J.; Bello-Pérez, L. Characterization of a fibre-rich powder prepared by liquefaction of unripe banana flour. Food Chem. 2008, 107, 1515-1521. [CrossRef]

136. Khoozani, A.A.; Bekhit, A.E.-D.A.; Birch, J. Effects of different drying conditions on the starch content, thermal properties and some of the physicochemical parameters of whole green banana flour. Int. J. Biol. Macromol. 2019, 130, 938-946. [CrossRef] [PubMed]

137. Dou, J.; Guo, Y.R.; Li, J.; Chen, W.Q.; Zhang, X.R. Purification and Characteristics of Polysaccharide TYAP-2 from Thinned Young Apples; Northwest A\&F University Press: Yangling, China, 2016; Volume 44, pp. 203-210. [CrossRef]

138. Viana, E.D.S.; Souza, A.D.S.; Reis, R.C.; Oliveira, V.J.D.S.D. Aplicação de farinha de banana verde na substituição parcial da farinha de trigo em pão de forma. Semina. Cienc. Agrár. 2018, 39, 2399-2408. [CrossRef]

139. Segundo, C.; Roman, L.; Gómez, M.; Martínez, M.M. Mechanically fractionated flour isolated from green bananas (M. cavendishii var. nanica) as a tool to increase the dietary fiber and phytochemical bioactivity of layer and sponge cakes. Food Chem. 2017, 219, 240-248. [CrossRef] [PubMed]

140. Wang, Y.; Zhang, M.; Mujumdar, A.S. Influence of green banana flour substitution for cassava starch on the nutrition, color, texture and sensory quality in two types of snacks. LWT 2012, 47, 175-182. [CrossRef]

141. De Matos, A.D.; Magli, M.; Marangon, M.; Curioni, A.; Pasini, G.; Vincenzi, S. Use of verjuice as an acidic salad seasoning ingredient: Evaluation by consumers' liking and Check-All-That-Apply. Eur. Food Res. Technol. 2018, 244, 2117-2125. [CrossRef]

142. Öncül, N.; Karabiyikli, Ş. Factors Affecting the Quality Attributes of Unripe Grape Functional Food Products. J. Food Biochem. 2015, 39, 689-695. [CrossRef]

143. Arevalo-Gallegos, A.; Ahmad, Z.; Asgher, M.; Parra, R.; Iqbal, H.M. Lignocellulose: A sustainable material to produce value-added products with a zero waste approach-A review. Int. J. Biol. Macromol. 2017, 99, 308-318. [CrossRef] [PubMed] 